\title{
Update on vaccination of preterm infants: a systematic review about safety and efficacy/ effectiveness. Proposal for a position statement by Italian Society of Pediatric Allergology and Immunology jointly with the Italian Society of Neonatology.
}

Elena Chiappini, Chiara Petrolini, Elena Sandini, Ameila Licari, Lorenza Pugni, Fabio A Mosca \& Gianluigi Marseglia

To cite this article: Elena Chiappini, Chiara Petrolini, Elena Sandini, Ameila Licari, Lorenza Pugni, Fabio A Mosca \& Gianluigi Marseglia (2019): Update on vaccination of preterm infants: a systematic review about safety and efficacy/effectiveness. Proposal for a position statement by Italian Society of Pediatric Allergology and Immunology jointly with the Italian Society of Neonatology., Expert Review of Vaccines, DOI: 10.1080/14760584.2019.1604230

To link to this article: https://doi.org/10.1080/14760584.2019.1604230

Accepted author version posted online: 05 Apr 2019.

Submit your article to this journal

View Crossmark data $\subsetneq$ 
Publisher: Taylor \& Francis

Journal: Expert Review of Vaccines

DOI: $10.1080 / 14760584.2019 .1604230$

\title{
Review
}

Update on vaccination of preterm infants: a systematic review about safety and efficacy/effectiveness. Proposal for a position statement by Italian Society of Pediatric Allergology and Immunology jointly with the Italian Society of Neonatology.

Elena Chiappini ${ }^{1}{ }^{*}$, Chiara Petrolini ${ }^{2}$, Elena Sandini ${ }^{2}$, Ameila Licari ${ }^{3}$, Lorenza Pugni ${ }^{4}$, Fabio A Mosca ${ }^{4,5}$ and Gianluigi Marseglia ${ }^{3}$

${ }^{1}$ Pediatric Infectious Disease Unit, Anna Meyer Children's University Hospital, Department of Health Science, University of Florence, Florence, Italy.

${ }^{2}$ Department of Health Sciences, University of Florence, Florence, Italy.

${ }^{3}$ Pediatric Clinic, IRCCS Policlinico "S. Matteo" Foundation, University of Pavia, Pavia, Italy.

${ }^{4}$ Neonatal intensive care unit, Fondazione IRCCS Ca' Granda Ospedale Maggiore Policlinico, Milan, Italy.

${ }^{5}$ University of Milan. Department of Clinical Sciences and Community Health, Milan, Italy.

*Corresponding author: Elena Chiappini, Pediatric Infectious Disease Unit, Anna Meyer Children's University Hospital, Florence, Viale Gaetano Pieraccini, 24,50139 Florence

Email: elena.chiappini@unifi.it

\begin{abstract}
Introduction: Preterm infants (PIs) are at increased risk of vaccine preventable diseases (VPDs). However delayed vaccination start and low vaccine coverage are still reported.
\end{abstract}

Areas covered: This systematic review includes 37 articles on preterm vaccination published in 2008-2018 in PubMed. Both live attenuated and inactivated vaccines are safe and well tolerated in PIs. Local reactions, apnea and reactivity changes are the most frequently reported adverse events. Lower gestational age and birth weight, preimmunization apnea, longer use of continuous positive airway pressure (CPAP) are risk factor for apnea. The proportion of PIs who develop protective humoral and cellular immunity is generally similar to full terms although later gestational age is associated to increased antibody IgG concentrations (i.e. against certain pneumococcal serotypes, influenza, hepatitis B virus and poliovirus 1 ) and increased mononuclear cells proliferation (i.e. after inactivated poliovirus). However vaccinated PIs have lower hospitalizations, ambulatory visits and notifications of VPDs.

Expert opinion: PIs can be safely and adequately protected by available vaccines with the same schedule used for full terms. However data at this regard have been almost exclusively retrieved by studies using a 3dose primary series for pneumococcal and hexavalent vaccines, while further studies are needed regarding the $2+1$ schedule. Apnea represents a nonspecific stress response in PIs, thus those hospitalized at 2 months should have cardio-respiratory monitoring for 2 days after their first vaccination.

Keywords: preterm infant, vaccinations, safety, immunogenicity, efficacy, effectiveness. 


\section{Article highlights}

- Despite recommendation to vaccinate preterm infants at the same scheduled age as full-term children, a delay is commonly experienced in these population.

- Preterm children may experience vaccine preventable diseases, which tend to be more severe, due to an impaired immune response

- Based on our research the overall safety and tolerability of the scheduled vaccines showed no differences in preterm and full-term infants, and live attenuated vaccines as well are considered safe.

- Postponing vaccination is justified only in clinically unstable infants

- Preterm infants already hospitalized at the time of first vaccination should receive their first dose in the neonatal ward, particularly those infants born $\leq 31$ weeks of gestation, those with a birth weight $2 \leq \mathrm{kg}$, those suffering from apnoea/bradycardia and those with severe bronchopulmonary dysplasia. There should then be monitoring of the clinical conditions and the cardio-respiratory system as inpatients for two days.

\section{1- Introduction}

Among the nearly 13 million preterm births occurring each year worldwide, approximately 500,000 occur in Europe where the preterm birth rate varies between $5 \%$ and $9 \%[1,2]$. In Italy, the proportion of preterm ( $<37$ weeks gestation) and very preterm ( $<32$ weeks gestation) births are about $7 \%$ and $1 \%$, respectively, corresponding approximately to 38,000 and 5500 live births annually [3]. -Preterm infants (PIs) may develop several long term adverse consequences, such as cerebral palsy, sensory deficits, respiratory illnesses, cognitive and behavioral disabilities [4-6], and are at increased risk of infections due to defects in external barriers, lower levels of passively transferred maternal antibody, innate and adaptive immunity impairment, with the latter resulting in suboptimal B and T cell function [7-9]. Therefore, preterm infants may experience vaccine preventable diseases (VPD) with increased frequency and severity in the first months of life [10-12], such as pertussis [13], pneumococcal infections [14], and influenza [15]. According to the international recommendations preterm infants, who are otherwise healthy, should follow the same vaccination schedule used for full-term infants, based on their chronological age rather than corrected gestational age and regardless of their birth weight. Moreover, vaccine dosages normally given to full term infants should not be reduced or divided when given to PIs [16-21].

However, low vaccination coverage and schedules' delayed start have been reported in PIs [22-29]. Delayed beginning of vaccines' schedules seems to be associated with low birthweight, lower gestational age, hospitalization after discharge from the neonatal intensive care units (NICUs), paternal/maternal unemployment, increasing numbers of siblings in the family, lower socioeconomic status and ethnicities other than white $[22,30]$. Fear of a weaker response to vaccines or of adverse events in preterm infants could be other reasons for the delay [31-34]; however several studies show that PIs are generally able to mount a protective adaptive immune response to most vaccines used in infant vaccination programmes [31, 35-36]. Moreover even if some adverse events like apnea and/or bradycardia have been reported to occur between 0 and $47 \%$ following vaccination in PIs, they are self-limiting non specific stress responses that commonly complicate other medical procedures without any long term sequelae [33-39]. The aim of the present study is to systematically review the available literature about vaccinations in PIs focusing on safety and immunogenicity/effectiveness.

\section{2- Methods}

A literature search was performed covering papers published from January 1st 2008 to $31^{\text {st }}$ October 2018. The PubMed MEDLINE and Cochrane Library databases were systematically searched using the following terms combined using Boolean operators ("infant, preterm"[MeSH Terms]) AND "vaccination"[MeSH terms]). Only papers published in English were included. Reference lists of the retrieved articles were reviewed to identify other possible pertinent publications. Titles and abstracts of studies identified during the primary search were screened for inclusion, and papers containing prospective or retrospective 
observational studies and clinical trials focusing on vaccination in PIs were included in this review. We included also studies assessing a comparison between full-term and PIs. Articles not pertinent to vaccines in PIs, commentaries, letters, case series (including less than 10 infants), case reports, reviews, duplicates and papers not written in English were excluded. Data were independently extracted by two different authors (CP and ES) and any disagreements or conflicts were discussed with a third author (EC). The following data were extracted for each study: year of publication, study type and location, gestational age (GA) of the study population, number of children included, type of vaccination administered, study outcomes (i.e.: laboratory indicators of immunogenicity; clinical indicators of efficacy or effectiveness; reported adverse events for vaccines' safety), follow up and possible biases and limitations of the study. The PRISMA Statement has been used for reporting of the systematic review filling a 27-item checklist (Table 1) and a four-phase flow diagram (Figure 1) [40].

\section{3-Results}

Initially, 61 studies were identified through the search strategy (Table 2) and additionally another 15 studies were retrieved after evaluation of the studies' references; 39 articles were excluded relying on studies' abstracts or titles because they didn't satisfy eligibility criteria (Figure 1).

Finally, 37 relevant articles were included in this systematic review: 24 articles had as the main objective vaccines' safety in preterm infants [34-35, 41-62]; while 18 and 4 articles investigated immunogenicity [31, $41-42,46-50,53-54,63-67,70,72,73]$ and effectiveness $[45,68-69,71]$ as the main objective respectively.

\section{1-Studies on vaccine safety.}

Safety was the main objective of 24 studies, overall including 789,165 preterm infants (Table 3) [34, 35, 4162].

\subsection{1-Studies on live attenuated vaccines'safety.}

Live attenuated vaccines were investigated in 6 studies [41-46]. Measles vaccination's safety was evaluated by Ichikawa et al. in a prospective study including 17 PIs $<34$ weeks of gestation who received an early vaccination at 6 months of age in order to prevent the disease. No adverse reaction was reported, but the number of vaccinated infants in the present study was limited [41].

Saroha et al. in a prospective randomized trial found that Bacille Calmette-Guérin (BCG) vaccine may be safely given at birth to moderately PIs (31-33 weeks). The only complication observed in $3.4 \%$ of the 117 patients enrolled in the study was left axillary lymphadenopathy [42]. Another two studies aimed to determine the safety of BCG vaccination [43-44]. Kjærgaard et al. performed two randomized multicenter clinical trials in Denmark, overall involving 4262 children, of which 144 were aged 32 to 37 weeks of gestation. No difference was observed on either susceptibility of infections, growth, body composition or psychomotor development between patients that received or did not receive BCG vaccination at birth [4344].

Two studies investigated safety of rotavirus vaccination in PIs [45-46]. A large population-based study by Rouè et al. showed no significant difference in severe adverse events incidence following rotavirus vaccination between preterm and full-term infants. [45]. Omenaca et al. in their phase IIlb randomized double blinded placebo-controlled trial including 165 PIs vaccinated with live-attenuated rotavirus observed a similar frequency of severe adverse events (SAEs) in the vaccinated and placebo groups ( $P=$ 0.266) [46]. The proportion of all and grade 3 solicited general adverse events (AEs) reported during the 15day postvaccination follow-up period were similar in both the vaccinated and placebo groups, with irritability as the most common AE [46]. The most commonly reported unsolicited AEs were fever, irritability, gastrointestinal disorders and upper respiratory tract infections. 3.1.2-Studies on inactivated or subunit vaccines' safety.

Inactivated or subunit vaccines were investigated in 18 studies [34-35,47-62] (Table 3). Tsuda et al. in a prospective cohort study reported local redness as the only AE after Haemophilus influenzae (Hib) vaccination in $54 \mathrm{PIs}$ [47]. Influenza A/H1N1 MF59-adjuvanted vaccination were studied by Esposito et al. in an open randomized trial including 101 infants. No difference in safety and tolerability were found between term and PIs. The only systemic adverse event consistently observed in all groups was fever, which was significantly more frequent after the first dose than after the second in all the groups [48]. 
An open-label prospective multicenter randomized controlled trial by Kent et al. evaluated the safety of the conjugate vaccine containing thirteen pneumococcal serotypes (PCV13) on PIs aged $<35$ weeks of gestation with different timing of administration: reduced schedule of PCV13 ( at 2 and 4 months of age), accelerated schedule (at 2, 3 and 4 months of age) and extended schedule (at 2, 4 and 6 months of age) [49]. There was no significant difference in the frequency or severity of local and systemic AEs between vaccination schedules at any time point and no serious AEs were considered vaccine related [49].

Several studies found a similar or sometimes lower frequency of AEs related to multivalent vaccines in PIs compared to full term infants, probably as the result of a reduced immune response and ability to mount an inflammatory process [50-54].

Klein et al. described adverse events related to diphtheria, tetanus, acellular pertussis (DTaP), hepatitis B (HBV), inactivated polio (IPV), pneumococcal vaccine (PCV) during the 30 days after each of 3 doses, comparing the frequency of AEs in preterm and full-term infants in 83 patients: no increase of medical attended events (MAEs) was found in the two groups comparing to the control period (postvaccination days 31-60)[50]. Moreover, in one retrospective study by McCrossan et al. none of the 344 PIs displayed an AE [51]. In a large observational self-controlled case series by Wilson et al. children acted as their own control counting the rate of events per day in an "at risk" period (i.e. immediate 3 days post vaccination at 2 months of age with DTaP-HBV-IPV-PCV) compared with the rate of events in a control period during which it would be unlikely that the exposure produced the outcome (9-18 days post-vaccination)[52]. Overall 771,453 children, of which 49,220 children $<37$ weeks of $G A$ and 7,392 children $\leq 32$ weeks of GA, were enrolled in the study, showing a progressive reduction in admission to emergency room department or to hospital 3 days after vaccination at 2 months of age with increasing category of prematurity [52]. Omeñaca et al. enrolled 313 term and PIs in an open controlled prospective multicenter study. Local symptoms in the 4 days following the combined Haemophilus influenzae type B-Neisseria meningitidis serogroup C vaccine (Hib-MenC-TT) were lower compared with DTaP-HBV-IPV-PCV vaccine [53]. Large injection-site swellings after the booster dose were reported less frequently in the preterm group than in full-term group, occurring mainly at the DTaP-IPV injection site. No difference in grade 3 AEs were found between groups [53]. Similarly, in another study, assessing the safety of the 10-valent pneumococcal non typeable Haemophilus influenzae protein D conjugate vaccine (PHiD-CV) in 149 term and 137 PIs, the incidence of solicited general symptoms (i.e: fever, irritability, drowsiness, loss of appetite) was generally similar across the groups [54]. Considering local symptoms, such as redness or swelling, their incidence was lower in PIs than in the term group [54]. None of the reported serious AEs was considered causally related to vaccination. The most frequently reported unsolicited AEs in all groups were upper respiratory tract infections, together with injection site nodules after primary and booster vaccination in the term group. One episode of apnea was reported in a PI after the first primary dose, but it was not considered to be associated to the vaccination and resolved without sequelae [54].

Wilinska et al. studied 138 children born before 37 weeks of gestation ( 73 born $\leq 28$ weeks GA and 65 born $>28$ weeks GA), who underwent vaccination as inpatient and monitored their cardiac and respiratory functions as well as body temperature over 72 hours after DTaP-IPV-PCV-Hib vaccination. Apnea and changes in reactivity (i.e. change in infants' behavior valued by Multidimensional Neonatal Infant Pain Scale-NIPS) were the relatively most frequent reported AEs. Infants who experienced apneas had significantly more frequently late onset sepsis and a history of longer use of continuous positive airway pressure (CPAP) [55].

Several studies found an increased incidence of apnea in PIs following vaccination with DTaP-IPV-PCV-Hib vaccine [34-35, 56-60]. Incidence of these reactions even if different in the reported studies declined with age, supporting the hypothesis that these cardiorespiratory events essentially represent nonspecific stress responses of very low birth weight (VLBW) PIs, whose maturity progresses with chronological age [34-35, 56-60]. In the study by Anderson et al. the incidence of apnea after the first DTaP-IPV- PCV-Hib vaccination was $8.4 \%$ in extremely PIs, while there was no reaction following the second dose at 4 months. Infants with apnea following the 2-month vaccine displayed significantly lower GA and birth weight. Unfortunately, only $50 \%$ cases with apnea after the first vaccination dose at 2 months were evaluated through a cardiorespiratory monitoring after the second dose at 4 months [56]. Similarly, in a prospective study by Furck et al. the risk of apnea decreased with increasing GA [57]. In this study the frequency of apnea/bradycardia after the first dose of DTaP-IPV-PCV-Hib vaccine in 473 preterm infants with a weight 
$<1500 \mathrm{~g}$ was $10.8 \%$ [57]. In a retrospective observational study by Flatz-Jequier et al. including 64 very low birth weight PIs aged $<32$ weeks, 33 infants developed a cardiorespiratory event after the first dose of DTaP-IPV-Hib vaccination and 6 of them required medical interventions after the second vaccine for a similar event, identifying a positive history of previous analogous $A E$ as a significant risk factor for the recurrence of a cardiorespiratory event [35]. In the study by Clifford et al. evaluating the frequency of apnea and bradycardia up to 48 hours after DTPa-IPV-HBV-Hib-PCV7 and oral rotavirus vaccine at 2 and 4 months of age, 7 out of 38 preterm infants developed recurrent apnea after vaccination. Lower birth weight and ongoing hospitalization for complications related to prematurity increased the risk of a recurrent apnea following vaccination [34]. Accordingly, a large multicenter retrospective cohort study by De Meo et al. including 13926 extremely PIs showed an increase in the respiratory support need in the 3 days following vaccination compared with the 3 days preceding the procedure, particularly in infants of 2334 weeks of GA compared with older PIs [58].

Other studies investigated possible risk factors for post-vaccination apnea other than lower GA, lower birth weight, lower chronological age and positive history of previous similar events [59-60].

A retrospective cohort study by Hacking et al. including 411 extremely PIs observed a higher incidence of apnea in PIs who had previously experienced septicemia and had a greater mean total accumulated time on CPAP prior to vaccination [59]. A multivariate analysis by Klein et al. identified age $\leq 31$ weeks of gestation, increased initial illness severity scores at birth, birth weight $<2 \mathrm{~kg}$ and the presence of pre-vaccination apnea as independent risk factors for post-vaccination apnea [60].

Conversely, the only available randomized blinded controlled multicenter study investigating the incidence of apnea in PIs found no increased incidence of post-vaccination apnea[61]. They investigated the frequency of cardiorespiratory events after DTaP vaccination at 2 months of age in 191 PIs with a GA<37 weeks. Infants were randomly assigned to a group that received DTaP vaccine or a control group that did not. No significant differences in apnoea or bradycardia frequency were found between the two groups [61].

A randomized double blinded placebo controlled trial by Ben Jmaa et al. included 56 PIs $<32$ weeks of gestation vaccinated at 2 months of age randomized in two group: the ibuprofen treatment group and the placebo group. Ibuprofen treatment significantly attenuated the variation of cardio-respiratory event following first vaccine. Authors speculated that the inflammatory processes triggered by vaccine might be responsible for the respiratory depression often observed in PIs and suggested a possible protective role of ibuprofen [62].

\section{2-Studies on vaccine immunogenicity and efficacy/effectiveness.}

Immunogenicity and efficacy/effectiveness was assessed in 22 studies overall including 1,566,350 infants (Table 4-5) [31, 41-42, 45-50, 53-54, 63-72].

\subsection{1-Studies on live attenuated vaccines' immunogenicity and efficacy/effectiveness.}

Live attenuated vaccines were investigated in 6 studies $[41,42,45,46,63,64]$. The immunogenicity of the early vs. delayed BCG vaccination (BCG at birth vs BCG at 34 weeks gestational age) in moderately preterm infants was studied by in-vivo (i.e. Mantoux test and scar formation 6 months after BCG vaccination) and invitro methods (i.e. rise IFN- $\gamma$ after BCG vaccination) by Saroha et al. The overall immunogenicity of BCG in this study was $98.3 \%$ independently from the time of vaccine administration. [42]. Even Faridi et al. in a prospective observational study evaluated the immunogenicity of BCG administered to infants of 31-41 weeks gestation within 7 days after birth. The $95.8 \%$ of enrolled patients had either a reactive Mantoux test or positive leukocyte migration inhibition test 6 months after BCG vaccination [63].

Ichikawa et al. investigated immunogenicity of anti-measles vaccine at 6 months of age in Pls $<34$ weeks of gestation. Early vaccination at 6 months reached protective antibody titers in all cases 1 month after vaccination without a decay during the 12 months after vaccine [41].

A prospective study by Ferreira et al. compared the immune response to measles and varicella vaccination in infants born prematurely with those born full-term. The proportion of infants with protective humoral titers to measles and varicella after vaccination were similar in both groups [64]. 
Two studies focused on rotavirus vaccine immunogenicity and effectiveness [46, 45]. Omenaca et al. assessed immunogenicity of rotavirus vaccine dosing IgA specific antibody 30-83 days post-dose 2 in a randomized double blind multicenter controlled trial. Seroconversion rate was $85.7 \%$ in the vaccine group and $16.0 \%$ in the placebo group [46]. Effectiveness of rotavirus vaccination was the topic of the study performed by Roue et al. with the aim to evaluate the impact of the pentavalent rotavirus vaccine on the number of hospitalizations for rotavirus diarrhoea in preterm infants. A significant decrease in the number of hospitalizations for rotavirus infection in infants younger than 3 years of age in the three epidemic seasons following the vaccine introduction was found [45].

3.2.2-Studies on inactivated or subunit vaccines' immunogenicity and efficacy/effectiveness. Tsuda et al. evaluated the immunogenicity of Hib vaccine in Pls evaluating antibody antipolyribosylribitolphosphate (PRP) geometric mean concentrations (GMCs) after the third dose of vaccine. The seroconversion rate was lower, but not significantly, in preterm than in full term infants $(85.2 \%$ vs. 92.4\%) [47].

Immunogenicity of pneumococcal vaccine was investigated in 6 studies $[31,49,54,65,66,67]$, while the assessment of the PCV effectiveness was the aim of one study [68]. Regarding immunogenicity results are discordant. Two studies $[54,65]$ reported protected specific antibody levels in high proportion of PIs, however several other authors found lower titers, especially against some serotypes such as $6 \mathrm{~B}$ and $23 \mathrm{~F}$ $[31,49]$.

A trial by Omenaca et al. assessed immunogenicity of the PHiD-CV in two groups of preterm infants (those born between 27 and 30 weeks vs. those born between 31-36 weeks). At least $93 \%$ and $97.6 \%$ of infants in each group reached protective antibody titers 1 month after primary vaccination and after the booster dose respectively, without any difference in antibody titers between groups [54]. Szynczewska et al. assessed the concentration of specific IgG against serotypes of PCV7 in 60 PIs [65]. Ninety-one $\%$ and 100\% of patients reached protective antibody concentrations after administration of three doses of the vaccine and after the booster dose respectively. Serotypes $6 \mathrm{~B}$ and $23 \mathrm{~F}$ were the least immunogenic ones[65]. On the other hand, only $36 \%$ term infants and $34 \%$ PIs achieved protective levels against all PVC7 vaccine serotypes following the primary vaccination [31]. Preterm birth adversely affected the GMCs to serotypes 4, 6B, 14, 19F, and 23F [31]. Immunogenicity of PCV13 was investigated in one RCT by Kent et al. including 199 Pls $<35$ weeks of GA, randomized to receive a reduced, accelerated and extended schedule of PCV13 [49]. Lack of seroprotection toward more than one-half of the PCV13 serotypes was seen in $25 \%, 12 \%$, and $3 \%$ of participants receiving the reduced, accelerated and extended schedules respectively. Waning of pneumococcal antibody concentrations was evident at 12 months of age. Later gestational age was associated with an increase in post-primary vaccination IgG concentrations for some serotypes, while receipt of antenatal steroids was associated with decreased odds of seroprotection after primary vaccination for some serotypes [49].

An open-label, multicenter trial by Martinón-Torres et al. evaluated antipneumococcal antibody responses elicited by PCV13 with a longer follow up, evaluating specific $\lg G$ antibody 1 and 2 years after the fourth dose (toddler dose) in PIs compared with term infants. IgG GMCs in both infant groups at the 1-year and 2year follow-up visits were lower than GMCs 1 month after the toddler dose for all serotypes. Particularly IgG GMCs in PIs were statistically significantly lower at both follow-up time points for serotypes 6B, 18C, $19 \mathrm{~A}, 19 \mathrm{~F}$ and $23 \mathrm{~F}$, while IgG GMCs for serotypes 5, 6A and $9 \mathrm{~V}$ were statistically significantly lower in PIs at the 1-year follow-up only [67].

Despite controversial immunogenicity results the only study investigating antipneumococcal effectiveness found reassuring results. Authors assessed the impact of PCV7 on invasive pneumococcal disease (IPD) in PIs comparing those born in 2000 (prior to the recommendation to vaccinate with PCV7 preterm infants) with those born in 2007. A reduction in notifications of IPD in 2007 was found both in full term and in PIs, although this reduction was not significant in the latter. No PIs with reported IPD received full vaccination with booster dose according to the recommended schedule. In two IPD cases were both not vaccinated and presented with a serotype included in PCV7 [68].

Two studies focused on influenza vaccine $[48,69]$. Esposito et al. evaluated the immunogenicity of influenza A/H1N1 MF59-adjuvanted vaccine measuring antibody immediately before administration of dose 1 and 2 and 4 weeks after the dose 2. GMCs were significantly higher after the second dose and significantly lower in PIs $<32$ weeks of gestation, thus confirming that a very low GA may lead to a reduced immune response. 
However seroprotection rates were $>90 \%$ after the first dose in all the groups, suggesting that a single dose of vaccine administered after the sixth month of life can protect almost all children aged $<23$ months [48]. Shen et al. examined influenza-related healthcare use outcomes among preterm and full-term children aged 6-23 months. The effectiveness of seasonal influenza vaccination was evaluated by examining influenza-coded ambulatory visits (physician office and ED visits) during influenza season periods over five years in more than 600,000 patients. Full vaccination was associated with an overall $19 \%$ reduction in ambulatory visits, however a significant reduction was observed only in full term infants [69].

Klein et al. investigated the immunogenicity of the primary series of IPV given as part of a combined vaccine evaluating poliovirus type 3-specific memory T cell, poliovirus type 3-specific cell-mediated immunity and neutralizing antibody response against poliovirus serotypes 1,2 and 3. Preterm and term infants developed comparable mean frequencies of poliovirus-specific memory $T$ cell responses. Considering mononuclear cells proliferation (PBMCs), PIs were significantly less likely to have a positive stimulation index (SI) than term infants, while all infants had a seroprotective antibody response to all 3 poliovirus serotypes. However the GMCs to poliovirus serotype 1 was significantly lower in both the group of all preterm infants [50]. Two studies investigated immunogenicity or effectiveness of pertussis vaccination in PIs [70-71]. Vermeulen et al. assessed the persistence of the specific immune responses against Bordetella pertussis in three groups of one-year old children born prematurely: one group received a whole cell vaccine (Pw) for the primary vaccination and a two components acellular vaccine ( $\mathrm{Pa}$ ) as booster dose; the second group received a two component $\mathrm{Pa}$ vaccine for every dose of the schedule, the third group received a three component Pa vaccine. The antigen specific cellular immune response persisted at year of age, however acellular vaccines induced a lower specific Th1 type immune response compared with Pw vaccine [70]. Hviid in a large retrospective nationwide Danish study observed a reduced immunogenicity of whole cell pertussis vaccine in PIs after the first dose but the completed primary series was equally effective in preterm and full-term children [71].

Omenaca et al. found an optimal immunogenicity of Hib-MenC-TT vaccine in 309 PIs [53]. In the same study anti-HBV IgG levels were also measured as secondary objectives after concomitant coadministration of DTaP-HBV-IPV showing a gestational age-related profile, with the lowest levels observed in infants aged $\leq 31$ weeks. Similar findings were evident in another study suggesting that PIs have lower humoral response to HBV than full-term infants in terms of GMCs but not in term of seroprotection rates[73].

\section{4-Conclusion}

Our findings are in general reassuring regarding the safety and immunogenicity of vaccines in PIs. Studies on BCG, rotavirus and measles vaccination found no increased risk of AEs. Considering inactivated/subunit vaccines, pain, redness and swelling in the injection site are frequently reported, as expected. However, large injection-site swellings after the booster dose have been reported less frequently in the preterm than in full-term infants by some authors [53,54, 74], but not by others [75-77]. Some authors postulated that a reduced immune response in PIs could result in fewer AEs immediately following vaccination [52]. Apnea and changes in activity (i.e. drowsiness, irritability and loss of appetite) were other frequently reported adverse events [53-55]. Incidence of cardiorespiratory events vary widely (from $1 \%$ to $59.1 \%$ of PIs) [34-35, 56-62]. Most cardiorespiratory events resolved spontaneously or required minimal intervention [35]. A causal relationship between vaccination and the occurrence of cardiorespiratory events continues to be widely debated. This may be due to the lack of a control group in many studies, their retrospective nature, sample sizes too small to demonstrate statistically significant differences, the difficulty in distinguishing apnea due to vaccination from background instability and the frequent presence of confounding factors (i.e.: periventricular hemorrhage, bronchopulmonary dysplasia, history of sepsis during hospitalization). Moreover, the incidence of post vaccination apnea could be influenced by the so-called "healthy vaccinated" effect, by which clinicians wait until infants are more stable to immunize, thus reducing the observed incidence of adverse events. However, the chance of experiencing an apnea after vaccination seems to be related with lower GA and birth weight $[56,60]$, supporting the hypothesis that these cardiorespiratory events essentially represent nonspecific stress responses of preterm infants $[35,58]$. Moreover, newborns who experienced apnea after vaccination were those with a previous severe clinical condition such as late onset sepsis or requiring long time CPAP support [55, 59]. One important risk factor 
for recurrence of cardiorespiratory event seems to be a positive history of previous similar adverse reaction, particularly in the $24 \mathrm{~h}$ prior to vaccine $[35,50,60,78]$.

Notably, the only controlled prospective randomized study by Carbone et al. [61] suggested that vaccination does not directly contribute to cardiorespiratory events showing no difference in occurrence or severity of apnea/bradycardia in vaccine recipients vs. controls. In this study clinical reviewers were blinded to vaccination status and study phase (before or after vaccination), but one possible bias of the study could be that PIs with unstable vital signs were excluded as were infants who required assisted ventilation.

In conclusion given the risks of cardio-respiratory events but also the increased risk of VPDs, PIs who are still hospitalized at 2 months of age should be vaccinated prior to discharge from hospital and should be monitored for $48-72 \mathrm{~h}$ after vaccination. This is particularly important in PIs with VLBW with a previous history of cardiorespiratory events, especially in the $24 \mathrm{~h}$ prior to vaccination. When a cardiorespiratory AE to the first dose is suspected, consideration should be given to administering the second vaccination under controlled circumstances.

Considering immunogenicity, the proportion of PIs who developed humoral immunity were generally similar in preterm compared with full term infants for many vaccines, with contrasting results for PCV vaccines, even if PCV7 effectiveness was found to be high in preterm infants in one study $[64,66,73]$. Good seroprotection rate for Hib, MenC, HBV, influenza and IPV vaccinations were reported in PIs $[47,48,50,53$, 72], even if lower gestational ages were associated to lower GMCs

in most of the studies and for most valences (i.e. HBV, Hib, IPV, influenza, pneumococcal and pertussis vaccine), suggesting a lower immunogenicity for PIs [31, 48, 50, 53, 67, 73].

Even if a possible impairment of Th1 response in PIs has been suggested [79-80], several results of studies documented an appropriate cellular immune response toward several vaccines (BCG, pertussis, IPV) [42, $50,63,70]$. One study reported imbalance in Th1/Th2 response in recipients of acellular pertussis vaccination, depending on the vaccine type, but clinical impact of such a finding is unclear [70]. Unfortunately, only 4 studies evaluating vaccine effectiveness (rotavirus, influenza, PCV, and pertussis) were retrieved $[45,68,69,71]$. Notably, all the large population based studies documented no differences in vaccine effectiveness between preterm and full term infants.

Our review presents several limitations: our literature search might have missed some studies. However, two authors independently performed literature searches in order to minimize this possibility. The study design of the retrieved papers varied and some of them included small datasets, especially for live attenuated vaccinations, thus further investigations are required. In addition, data about extreme PIs are poor and a distinction of results according to grade of prematurity is not always performed in the studies enrolled.

\section{5-Expert opinion}

Neither gestational age nor birth weight should delay the decision to start vaccination in clinically stable PIs. Postponing vaccination is justified only in clinically unstable infants. If PIs are still hospitalized at the time at which they should be vaccinated they should receive their first vaccine in the neonatal ward monitoring them for $48-72 \mathrm{~h}$ after vaccination. This is particularly important for infants born $\leq 31$ weeks of $\mathrm{GA}$, with birth weight $<2 \mathrm{Kg}$, with pre-vaccination apnea episodes or with severe bronchopulmonary dysplasia. Educational programs for health professionals and caregivers should be improved in order to avoid delay in vaccination of these infants.

Most of the available studies comparing the immunogenicity of DTaP-IPV-Hib-HBV and PCV in preterm and full term infants apply a 3-dose primary series of vaccination $[31,45,50,53-54,65,67-71,73]$ as recommended by the Centers for Disease Control and Prevention [81]. Even if many countries like United Kingdom, Australia and Canada adopt a 3-dose primary series, other European countries, including Italy, apply a 2+1-dose primary series for hexavalent/pentavalent and pneumococcal vaccination.

Currently only one study compared different schedules of immunization with PCV13 [49], showing lower specific IgG GMCs with the reduced schedule after the primary course but superior antibody concentrations after the booster dose in comparison with extended or accelerated schedules. According to some experts' opinions, it could be preferable to vaccinate very PIs with a 3-dose primary series of DTaP-IPV-HBV-Hib and PCV. However, further studies are needed in order to better understand the immunogenicity of the $2+1$ schedule in very PIs ( $<32$ weeks of gestational age). 
Specific issues should be considered regarding rotavirus vaccination considering the risk of transmission of the live attenuated virus in the stool of immunized PIs still hospitalized in NICUs. Several international guidelines recommend that rotavirus vaccine should be administered within 6 to 14 weeks and 6 days of age in order to minimize the potential risk of intussusception $[82,83,84]$. Canadian and American guidelines suggest rotavirus vaccine administration at or following discharge from the NICUs to prevent the spread of vaccine virus in the hospital setting with the risk of missing possible cardiorespiratory events but also the risk of missing the benefit of rotavirus vaccination in term of immunogenicity overcoming the specific time of administration of vaccine [82-83]. A possible compromise could be policy adopted by British guidelines recommending to vaccine PIs still hospitalized applying routine standard infection control precautions [84]. Further studies are needed to develop evidence-based recommendations regarding the necessity to monitor Pls with suspected cardio-respiratory event following the first vaccine when the second immunisation is performed, considering also direct and indirect costs of a prolonged hospitalization.

Although several studies have been retrieved, limited data are available regarding vaccine effectiveness in preterm infants, particularly after the schedule $2+1$ for the hexavalent vaccine and PCVs. Therefore, further studies are needed in this respect, especially focusing on the more recently marketed vaccines (i.e. PCV13 and anti-meningococcal vaccines) and on the need for eventual additional booster doses. Moreover, future studies should analyse the potential differences between subgroups of preterm infants, such as extremely preterm ones ( $<29$ weeks gestational age) to assess whether they need additional vaccine or earlier booster doses.

\section{Funding}

This paper was not funded.

\section{Declaration of interests}

The authors have no relevant affiliations or financial involvement with any organization or entity with a financial interest in or financial conflict with the subject matter or materials discussed in the manuscript. This includes employment, consultancies, honoraria, stock ownership or options, expert testimony, grants or patents received or pending, or royalties.

\section{Reviewer disclosures}

Peer reviewers on this manuscript have no relevant financial or other relationships to disclose

\section{Acknowledgments}

The authors would like to show their gratitude to Duse M., Minasi D., Miraglia Del Giudice M. , Cardinale F. , Caffarelli C. , Calvani M., Martelli A., Pajno GB. , Tosca M., Manti S as members of the governing board of the Italian Society of Pediatric Allergology and Immunology (SIAIP) and thank the reviewers for their insights.

\section{References}

Papers of special note have been highlighted as either of interest $(\bullet)$ or of considerable interest $(\bullet \bullet)$ to readers.

1. Beck S, Wojdyla D, Say L, Betran AP, Merialdi M, Requejo JH, Rubens C, Menon R, Van Look PF. The worldwide incidence of preterm birth: a systematic review of maternal mortality and morbidity. Bull World Health Organ.2010;88:31-8.

2. Zeitlin J, Mohangoo AD, Delnord M, Cuttini M, The EURO-PERISTAT Scientific Committee. The second European Perinatal Health Report: documenting changes over 6 years in the health of mothers and babies in Europe. J Epidemiol Community Health.2013;67:983-5

3. Ministero della Salute. Certificato di assistenza al parto. In: Analisi dell'evento nascita; 2012, http://www.salute.gov.it/imgs/C 17 pubblicazioni 1731 allegato.pdf (Accessed August 2013). 
4. Woodward LJ, Moor S, Hood KM, et al. Very preterm children show impairments across multiple neurodevelopmental domains by age 4 years. Arch Dis Child Fetal Neonatal Ed 2009;94:F339-44.

5. Dall'Oglio AM, Rossiello B, Coletti MF, Bultrini M, DE Marchis C, et al. Do healthy preterm children need neuropsychological follow-up? Preschool outcomes compared with term peers. Dev Med Child Neurol.2010;52(10):955-61.

6. Saigal S, Doyle LW. An overview of mortality and sequelae of preterm birth from infancy to adulthood. Lancet.2008;371:261-9.

7. Crawford NW, Bines JE, Royle J, Buttery JP. Optimizing immunization in pediatric special risk groups. Expert Rev Vaccines.2011;10:175-86

8. Palmeira P, Quinello C, Silveira-Lessa AL, Zago CA, Carneiro-Sampaio M. IgG placental transfer in healthy and pathological pregnancies. Clin Dev Immunol.2012;2012:985646.

9. Siegrist CA, Córdova M, Brandt C, Barrios C, Berney M, Tougne C, Kovarik J, Lambert PH. Determinants of infant responses to vaccines in presence of maternal antibodies. Vaccine.1998;16:1409-14.

10. Bonhoeffer J, Siegrist CA, Heath PT. Immunisation of premature infants. Arch Dis Child.2006;91:929-35.

11. Lawn JE, Osrin D, Adler A, Cousens S. Four million neonatal deaths: counting and attribution of cause of death. Paediatr Perinat Epidemiol.2008;22:410-6.

12. Stoll BJ, Hansen N, Fanaroff AA, et al. Late-onset sepsis in very low birth weight neonates: the experience of the NICHD Neonatal Research Network. Pediatrics.2002;110:285-91.

13. Langkamp DL, Davis JP. Increased risk of reported pertussis and hospitalization associated with pertussis in low birth weight children. J Pediatr.1996;128:654-9.

14. Shinefield $\mathrm{H}$, Black S, Ray $\mathrm{P}$, et al. Efficacy, immunogenicity and safety of heptavalent pneumococcal conjugate vaccine in low birth weight and preterm infants. Pediatr Infect Dis J.2002;21:182-6.

15. Grohskopf LA, Sokolow LZ, Broder KR, Walter EB, Fry AM, Jernigan DB. Prevention and Control of Seasonal Influenza with Vaccines: Recommendations of the Advisory Committee on Immunization Practices-United States, 2018-19 Influenza Season. MMWR Recomm Rep. 2018;67:1-20.

16. Pickering LK, Baker CJ and Kimberlin DW, Preterm and low birth weight infants. In Red Book 2012, Report of the Committee on Infectious Diseases. 29th Edition ed Elk Grove Village, IL: American Academy of Pediatrics.2012.p 69-71.

17. American Academy of Pediatrics (2015). Red book online: Immunization in preterm and low birth weight infants. Retrieved from http://redbook.so lutions.aap.org/chapter.aspx?sectionld=88187007\&bookld=1484\&resultClick=1 on 20 April 2016.

18. Australian Government (2016). The Australian immunisation handbook; Groups with special vaccination requirements. Retrieved from http:// www.immunise.health.gov.au/internet/immunise/publishing.nsf/Conte nt/Handbook10home handbook10part3 handbook10-3-3\#3-3-2 on 20 April 2016

19. Davis RL, Rubanowice D, Shinefield HR, et al. Immunization levels among premature and low-birthweight infants and risk factors for delayed up-to-date immunization status. Centers for Disease Control and Prevention Vaccine Safety Datalink Group. JAMA.1999;282:547-53.

20. Doherty M, Schmidt-Ott R, Santos JI, Stanberry LR, Hofstetter AM, Rosenthal SL et al. Vaccination of special populations: Protecting the vulnerable. Vaccine. 2016;34:6681-90.

21. Saari TN, American Academy of Pediatrics Committee on Infectious Diseases. Immunization of preterm and low birth weight infants. American Academy of Pediatrics Committee on Infectious Diseases. Pediatrics.2003;112:193-8.

22. Sisson H, Gardiner E, Watson R, Vaccination timeliness in preterm infants: An integrative review of the literature. J Clin Nurs.2017;26:4094-104.

23. Woestenberg PJ, van Lier A, van der Maas NA, Drijfhout IH, Oomen PJ, de Melker HE. Delayed start of diphtheria, tetanus, acellular pertussis and inactivated polio vaccination in preterm and low birth weight infants in the Netherlands. Pediatr Infect Dis J.2014;33:190-8.

24. Gad A, Shah S. Special immunization considerations of the preterm infant. J Pediatr Health Care.2007;21:385-91. 
25. Salmon DA, Dudley MZ, Glanz JM, Omer SB. Vaccine hesitancy: Causes, consequences, and a call to action. Vaccine.2015;33:D66-71.

26. Batra SJ, Eriksen EM, Zangwill KM, Lee M, Marcy SM et al, Evaluation of Vaccine Coverage for Low Birth Weight Infants During the First Year of Life in a Large Managed Care Population.

Pediatrics.2009;123:951-958

27. Crawford NW,Yeo V, Hunt RW, Barfield C, Gelbart B et al. Immunisation practices in infants born prematurely: Neonatologists' survey and clinical audit. Journal of Paediatrics and Child Health.2009;45:602-60.

28. Denizot S, Fleury J, Caillaux G, V. Rouger V, Rozé J-C et al, Hospital initiation of a vaccinal schedule improves the long-term vaccinal coverage of ex-preterm children. Vaccine.2011;29: 382-86.

29. Cerutti M, De Lonlay P, Menni F, Parini R, Principi N, Esposito S. Vaccination coverage of patients with inborn errors of metabolism and the attitudes of their parents towards vaccines. Vaccine.2015;33:6520-4.

30. Tozzi AE, Piga S, Corchia C, Di Lallo D, Carnielli V et al, Timeliness of routine immunization in a population-based Italian cohort of very preterm infants: Results of the ACTION follow-up project. Vaccine 2014; 32:793- 99.

*An evaluation of the coverage and timeliness of routine immunizations assessing the determinants of immunization delay in a large, prospective area-based Italian cohort of VPI followed up at 2 years of age*

31. Moss SJ, Fenton AC, Toomey JA, Grainger AJ, Smith J, Gennery AR. Responses to a conjugate pneumococcal vaccine in preterm infants immunized at 2,3, and 4 months of age. Clin Vaccine Immunol.2010;17:6-1810.

32. Vázquez L, Garcia F, Rüttimann R, Coconier G, Jacquet JM, et al. Immunogenicity and reactogenicity of DTPa-HBV-IPV/Hib vaccine as primary and booster vaccination in low-birth-weight premature infants. Acta Paediatr.2008;97:9-1243.

33. Clifford V, Crawford NW, Royle J, Lazzaro T, Danchin M, et al. Recurrent apnoea post immunisation: informing re-immunisation policy. Vaccine.2011;29:7-5681.

34. Flatz-Jequier A, Posfay-Barbe KM, Pfister RE, Siegrist CA. Recurrence of cardiorespiratory events following repeat DTaP-based combined immunization in very low birth weight premature infants. J Pediatr.2008;153:429-31.

35. Rückinger $S$, van der Linden $M$, von Kries R. Effect of heptavalent pneumococcal conjugate vaccination on invasive pneumococcal disease in preterm born infants. BMC Infect Dis.2010;10:12. doi: 10.1186/1471-2334-10-12.

36. D'Angio CT, Boohene PA, Mowrer A, Audet S, Menegus MA, Schmid DS, Beeler JA.Measlesmumps-rubella and varicella vaccine responses in extremely preterm infants. Pediatrics.2007;119:9-574.

37. Schulzke $S$, Heininger $U$, Lücking-Famira M, Fahnenstich $H$. Apnoea and bradycardia in preterm infants following immunisation with pentavalent or hexavalent vaccines. Eur J Pediatr.2005;164:5432.

38. Faldella G, Galletti S, Corvaglia L, Ancora G, Alessandroni R. Safety of DTaP-IPV-HIb-HBV hexavalent vaccine in very premature infants. Vaccine.2007;25:1036-42.

39. Lee J, Robinson JL, Spady DW. Frequency of apnea, bradycardia, and desaturations following first diphtheria-tetanus-pertussis-inactivated polio-Haemophilus influenzae type B immunization in hospitalized preterm infants. BMC Pediatr.2006;6:20.

40. Liberati A, Altman DG, Tetzlaff J, Mulrow C, Gøtzsche PC et al. The PRISMA Statement for Reporting Systematic Reviews and Meta-Analyses of Studies That Evaluate Health Care Interventions: Explanation and Elaboration. Plos Medicine.2009; 6:1-28.

41. Ichikawa T, Tsuji A, Fujino M, Kusano R, Sugiyama R, Oomori $S$ et al. Effect of early measles vaccination (AIK-C strain) for preterm infants. Pediatr Int.2013;55:163-8.

42. Saroha M, Faridi MM, Batra P, Kaur I, Dewan DK. Immunogenicity and safety of early vs delayed BCG vaccination in moderately preterm (31-33 weeks) infants. Hum Vaccin Immunother.2015;11:2864-71 
43. Kjærgaard J, Stensballe LG, Birk NM, Nissen TN, Thøstesen LM, et al. Bacillus Calmette-Guérin vaccination at birth: Effects on infant growth. A randomized clinical trial. Early Hum Dev.2016;100:49-54

44. Kjærgaard J, Stensballe LG, Birk NM, Nissen TN, Foss KT, Thøstesen LM et al. Lack of a Negative Effect of BCG-Vaccination on Child Psychomotor Development: Results from the Danish Calmette Study - A Randomised Clinical Trial. PLoS One.2016;11:e0154541.

45. Roué JM, Nowak E, Le Gal G, Lemaitre T, Oger E et al, Impact of Rotavirus Vaccine on Premature Infants. Clinical and Vaccine Immunology.2014;21:1404-09.

46. Omenaca F, Sarlangue J, Szenborn L, Nogueira M, Suryakiran PV, Smolenov IV et al. Safety, reactogenicity and immunogenicity of the human rotavirus vaccine in preterm European Infants: a randomized phase IIIb study. Pediatr Infect Dis J.2012;31:487-93.

*An assessment of the safety, reactogenicity and immunogenicity of rotavirus vaccine in European preterm infants by a prospective randomized, double-blind placebo-controlled multicentre trial*.

47. Tsuda K, Iwasaki S, Horiguchi H, Mori M, Nishimaki S, Seki K et al. Immune response to Haemophilus influenzae type $b$ conjugate vaccine in preterm infants. Pediatr Int.2012;54:64-7.

48. Esposito S, Pugni L, Daleno C, Ronchi A, Valzano A, Serra D et al. Influenza A/H1N1 MF59adjuvanted vaccine in preterm and term children aged 6 to 23 months. Pediatrics.2011;127:e11618.

*A prospective randomized study about immunogenicity and safety of a monovalent 2009 pandemic influenza A/H1N1 MF59-adjuvanted vaccine involving children aged 6 to 23 months of different gestational age*

49. Kent A, Ladhani SN, Andrews NJ, Scorrer T, Pollard AJ, Clarke P et al. Schedules for Pneumococcal Vaccination of Preterm Infants: An RCT. Pediatrics.2016;138: e20153945-56.

50. Klein NP, Gans HA, Sung P, Yasukawa LL, Johnson J, Sarafanov A et al. Preterm infants' T cell responses to inactivated poliovirus vaccine. J Infect Dis. 2010;201:214-22.

51. McCrossan P, McCafferty C, Murphy C, Murphy J. Retrospective review of administration of childhood primary vaccination schedule in an Irish tertiary neonatal intensive care unit. Public Health.2015; 30:1-3

52. Wilson $\mathrm{K}$, Hawken S. Incidence of adverse events in premature children following 2-month vaccination. Hum Vaccin Immunother.2012;8:592-5.

53. Omeñaca F, Arístegui J, Tejedor JC, Moreno-Perez D, Ruiz-Contreras J, Merino JM et al. Combined Haemophilus Influenzae type B-Neisseria meningitidis serogroup $C$ vaccine is immunogenic and well tolerated in preterm infants when coadministered with other routinely recommended vaccines. Pediatr Infect Dis J.2011;30:e216-24.

54. Omeñaca F, Merino JM, Tejedor JC, Constantopoulos A, Papaevangelou V, Kafetzis D et al. Immunization of preterm infants with 10-valent pneumococcal conjugate vaccine.

Pediatrics.2011;128:e290-8.

*An evaluation of safety and immunogenicity of the 10 -valent pneumococcal non typeable Haemophilus influenzae protein D conjugate vaccine (PHiD-CV) in preterm infants of different gestational age.*

55. Wilińska M, Warakomska M, Głuszczak-Idziakowska E, Jackowska T. Risk factors for adverse events after vaccinations performed during the initial hospitalization of infants born prematurely. Developmental Period Medicine. 2016;20,296-305.

56. Anderson J, Noori K and Morris SA. Apnoea after the 2-month immunisation in extremely preterm infants: What happens with the 4-month immunisation? Journal of Paediatrics and Child Health.2013;49: E217-E220

57. Furck AK, Richter JW and Kattner E. Very low birth weight infants have only few adverse events after timely immunization. Journal of Perinatology.2010; 30:118-21

58. DeMeo SD, Raman SR, Hornik CP, Wilson C, Clark R et al. Adverse Events After Routine Immunization of Extremely Low Birth Weight Infants. JAMA Pediatr.2015; 169: 740-45.

59. Hacking DF, Davis PG, Wong E, Wheeler K, McVernon J. Frequency of respiratory deterioration after immunisation in preterm infants. Journal of Paediatrics and Child Health.2010; 46:742-8 
60. Klein NP, Massolo ML, Greene J, Dekker CL, Black S. Risk Factors for Developing Apnea After Immunization in the Neonatal Intensive Care Unit. Pediatrics.2008;121:463-9.

*An assessment of factors associated with postimmunization apnea using multivariate logistic regression in a cohort of infants immunized in the NICU.*

61. Carbone T, McEntire B, Kissin D, Kelly D, Steinschneider A, Violaris K et al. Absence of an increase in cardiorespiratory events after diphtheria-tetanus-acellular pertussis immunization in preterm infants: a randomized, multicenter study. Pediatrics.2008;121:e1085-90.

* The only prospective, blinded, controlled, randomized, multicenter study reexamining the relationship between diphtheria-tetanus-acellular pertussis and cardiorespiratory events in preterm infants. *

62. Ben Jmaa W, Hernández Al, Sutherland MR, Cloutier A, Germain N, Lachance C et al. Cardiorespiratory Events and Inflammatory Response After Primary Immunization in Preterm Infants $<32$ Weeks Gestational Age: A Randomized Controlled Study. Pediatr Infect Dis J.2017;36:988-94.

63. Faridi M, Kaur S, Krishnamurthy S, Kumari P. Tuberculin conversion and leukocyte migration inhibition test after BCG vaccination in newborn infants. Hum Vaccin.2009;5:690-5.

64. Ferreira CSM, Perin MCAA, de Moraes-Pinto MI, Simão-Gurge RM, Goulart AL et al. Humoral immune response to measles and varicella vaccination in former very low birthweight preterm infants. Braz J Infect Dis.2018. 22:41-46

65. Szynczewska E, Chlebna-Soko D. Immunogenicity of Heptavalent Conjugate Vaccine Against Streptococcus pneumoniae in Premature Babies with Low Birth Weight. Pediatrics and Neonatology.2014; 55:101-7.

66. Van den Berg JP, Westerbeek EAM, Van der Klis, Sanders EAM, MD, Berbers GAM et al. Response on Pneumococcal Vaccine in Preterm Infants After Neutral and Acidic Oligosaccharides Supplementation. The Pediatric Infectious Disease Journal.2015; 34: 976:82.

67. Martinón-Torres F, Wysocki J, Center KJ, Czajka H, Majda-Stanislawska E, Omeñaca F et al. Circulating Antibody 1 and 2 Years After Vaccination With the 13-Valent Pneumococcal Conjugate Vaccine in Preterm Compared With Term Infants. Pediatr Infect Dis J.2017;36:326-332.

68. Rückinger S, Van der Linden M, Von Kries R. Effect of heptavalent pneumococcal conjugate vaccination on invasive pneumococcal disease in preterm born infants. BMC Infectious Diseases.2010;10:12-6.

69. Shen S, Campitelli MA, Calzavara A, Guttmann A, Kwong JC. Seasonal influenza vaccine effectiveness in pre- and full-term children aged 6-23 months over multiple seasons. Vaccine.2013;31:2974-8.

*An evaluation of the effectiveness of seasonal influenza vaccination in all pre- and full-term in a large population study*

70. Vermeulen F, Dirix V, Verscheure V, Damis E, Vermeylen D, Locht C et al. Persistence at one year of age of antigen-induced cellular immune responses in preterm infants vaccinated against whooping cough: comparison of three different vaccines and effect of a booster dose. Vaccine.2013;31:19816.

71. Hviid A. Effectiveness of two pertussis vaccines in preterm Danish children. Vaccine.2009;27:30358. *A nationwide cohort study of 879,424 Danish children about effectiveness of pertussis vaccination, both whole-cell and acellular in preterm and full-term children. *

72. Baxter D, Ghebrehewet S, Welfare W, Ding DC. Vaccinating premature infants in a Special Care Baby Unit in the UK: results of a prospective, non-inferiority based, pragmatic case series study. Hum Vaccin.2010;6:512-20.

73. Omeñaca F, Garcia-Sicilia J, Boceta R, García-Corbeira P. Hepatitis B response of premature infants after primary and booster immunisation with a diphtheria-tetanus-acellular pertussis-hepatitis Binactivated poliovirus/haemophilus influenzae type B vaccine. Infect Dis Obstet Gynecol.2010;2010:802503.

74. Adam D, Fehnle K. Safety and effectiveness against respiratory tract infections for pneumococcal conjugate vaccine coadministered with routine vaccine combinations. Vaccine.2008;26:5944-51 
75. Shinefield H,Black S, Ray P, Fireman B, Schwalbe J, Lewis E. Efficacy, immunogenicity and safety of heptavalent pneumococcal conjugate vaccinein low birth weight and preterm infants. Pediatr Infect Dis J.2002;21:182-6

76. Omeñaca F, Garcia-Sicilia J, Garcia-Corbeira P, et al. Response of preterm newborns to immunization with a hexavalent diphtheria tetanus-acellular pertussis-hepatitis $B$ virus-inactivated polio and Haemophilus influenzae type $b$ vaccine: first experiences and solutions to a serious and sensitive issue. Pediatrics.2005;116:1292-98

77. Omeñaca F, Garcia-Sicilia J, Boceta R, Sistiaga Hernando A, Garcia-Corbeira P. Antibody persistence and booster vaccination during the second and fifth years of life in a cohort of children who were born prematurely. Pediatr Infect Dis J.2007;26:824-9

78. Pfister RE, Aeschbach V, NiksicStuber V. Safety of DtaP based combined immunization in very low birth weight premature infants frequent but mostly benign cardiorespiratory events. $J$ Pediatr.2004;145:58-66.

79. Advisory Committee on Immunization Practices. Preventing pneumococcal disease among infants and young children. Recommendations of the Advisory Committee on Immunization Practices (ACIP). MMWR Recomm Rep.2000; 49:1e35.

80. Esposito S, Fumagalli M and Principi N. Immunogenicity, safety and tolerability of vaccinations in premature infants. Expert Rev Vaccines.2012;11:1199-209.

81. Robinson CL, Bernstein H, Romero JR, Szilagyi P. Advisory Committee on Immunization Practices Recommended Immunization Schedule for Children and Adolescents Aged 18 Years or Younger United States, 2019. Weekly 2019; 68:112-4.

82. Armstrong C, Practice Guidelines: AAP Updates Guidelines on Rotavirus Vaccination. Am Fam Physician. 2010;81:552-53.

83. National advisory committee on immunization. Litterature review on Rotavirus: disease and vaccine characteristics. Can commun Dis Rep 2010; 36:1-31.

84. Immunisation against infectious disease (the Green Book) www.gov.uk/government/publications/rotavirus-the-green-book-chapter-27b.Ref: PHE publications gateway number 2018748

\section{Table and figure legends}

Table 1: PRISMA 2009 Checklist filled out [40].

Table 2: Sixty-one articles identified with the search details (infant, preterm"[MeSH Terms]) AND "vaccination"[MeSH terms] and exclusion criteria for the screening relying on studies' abstracts or titles.

Table 3: Studies regarding vaccine safety in preterm infants. 
[Notes: $\mathrm{DTaP}=$ diphtheria, tetanus, acellular pertussis vaccine; IPV= inactivated polio vaccine; $\mathrm{OPV}=$ oral polio vaccine; $H B V=$ hepatitis $B$ vaccine; $P C V 7$ heptavalent antipneumococcal vaccine; $P C V 13=$ tridecavalent antipneumococcal vaccine; $\mathrm{Hib}=$ type $\mathrm{B}$ Haemophilus influenzae vaccine; Hib-MenC-TT= Haemophilus

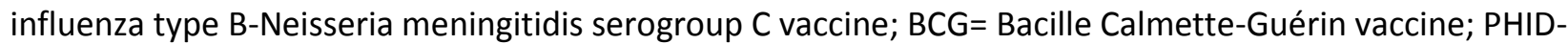
$\mathrm{CV}=\mathrm{PCV} 10$-non typeable H.influenzae protein D conjugate vaccine; SNAP-II: Score for Neonatal Acute Physiology II (SNAP-II); AOR=adjusted odd ratio; $\mathrm{Cl}=$ confidence interval].

Table 4: Studies regarding vaccine immunogenicity in preterm infants [Notes: $\mathrm{DTaP}=$ diphtheria, tetanus, acellular pertussis vaccine; IPV= inactivated polio vaccine; $\mathrm{OPV}=$ oral polio vaccine; $H B V=$ hepatitis $B$ vaccine; $P C V 7$ heptavalent antipneumococcal vaccine; $P C V 13=$ tridecavalent antipneumococcal vaccine; $\mathrm{Hib}=$ type $B$ Haemophilus influenzae vaccine; Hib-MenC-TT= Haemophilus

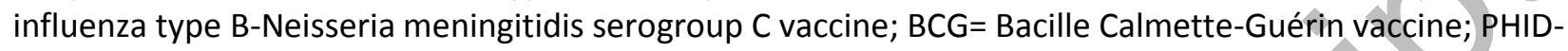
$\mathrm{CV}=\mathrm{PCV} 10$-non typeable $\mathrm{H}$. influenzae protein $\mathrm{D}$ conjugate vaccine; $\mathrm{FHA}=$ filamentous haemagglutinin; PT=pertussis toxin; PRN=pertactin; OPA=opsonophagocytic activity; SNAP-II: Score for Neonatal Acute Physiology II (SNAP-II), MMR=measles, mumps, and rubella vaccine; GMCs= geometric mean concentrations; PRP= anti-polyribosylribitolphosphate; IPD= invasive pneumococcal disease; LMIT=leukocyte migration inhibition test; SBAMenC=seroprotective serum bactericidal activity thresholds against meningococcal serogroup $C$ vaccine].

Table 5: Studies regarding vaccine effectiveness in preterm infants.

[Notes: $\mathrm{DTaP}=$ diphtheria, tetanus, acellular pertussis vaccine; $\mathrm{PVV}=$ inactivated polio vaccine; $\mathrm{OPV}=$ oral polio vaccine; $H B V=$ hepatitis $B$ vaccine; $P C V 7$ heptavalent antipneumococcal vaccine; $P C V 13=$ tridecavalent antipneumococcal vaccine; $\mathrm{Hib}=$ type $\mathrm{B}$ Haemophilus influenzae vaccine; Hib-MenC-TT= Haemophilus influenza type B-Neisseria meningitidis serogroup C vaccine; BCG= Bacille Calmette-Guérin vaccine; PHID$\mathrm{CV}=$ PCV10-non typeable $\mathrm{H}$. influenzae protein D conjugate vaccine; SNAP-II: Score for Neonatal Acute Physiology II (SNAP-II), MMR=measles, mumps, and rubella vaccine; GMCs= geometric mean concentrations; $\mathrm{PRP}=$ anti-polyribosylribitolphosphate; IPD= invasive pneumococcal disease; LMIT=leukocyte migration inhibition test, IC=interval confidence; $E D=e m e r g e n c y$ department; $H R=$ Adjusted hazard ratios; $\mathrm{Pw}=$ pertussis whole vaccine; $\mathrm{Pa}=$ pertussis acellular vaccine].

Figure 1: Four-phase flow diagram of the systematic review in accordance with PRISMA guidelines [40]. 


\begin{tabular}{|c|c|c|c|}
\hline Section/topic & $\#$ & Checklist item & $\begin{array}{l}\text { Reported } \\
\text { on page \# }\end{array}$ \\
\hline \multicolumn{4}{|l|}{ TITLE } \\
\hline Title & 1 & $\begin{array}{l}\text { Identify the report as a systematic review, meta-analysis, or } \\
\text { both. }\end{array}$ & 1 \\
\hline \multicolumn{4}{|l|}{ ABSTRACT } \\
\hline $\begin{array}{l}\text { Structured } \\
\text { summary }\end{array}$ & 2 & $\begin{array}{l}\text { Provide a structured summary including, as applicable: } \\
\text { background; objectives; data sources; study eligibility } \\
\text { criteria, participants, and interventions; study appraisal and } \\
\text { synthesis methods; results; limitations; conclusions and } \\
\text { implications of key findings; systematic review registration } \\
\text { number. }\end{array}$ & 1 \\
\hline \multicolumn{4}{|c|}{ INTRODUCTION } \\
\hline Rationale & 3 & $\begin{array}{l}\text { Describe the rationale for the review in the context of what is } \\
\text { already known. }\end{array}$ & 1 \\
\hline Objectives & 4 & $\begin{array}{l}\text { Provide an explicit statement of questions being addressed } \\
\text { with reference to participants, interventions, comparisons, } \\
\text { outcomes, and study design (PICOS). }\end{array}$ & 2 \\
\hline \multicolumn{4}{|l|}{ METHODS } \\
\hline $\begin{array}{l}\text { Protocol and } \\
\text { registration }\end{array}$ & 5 & $\begin{array}{l}\text { Indicate if a review protocol exists, if and where it can be } \\
\text { accessed (e.g., Web address), and, if available, provide } \\
\text { registration information including registration number. }\end{array}$ & $\begin{array}{l}\text { Not } \\
\text { applicable }\end{array}$ \\
\hline $\begin{array}{l}\text { Eligibility } \\
\text { criteria }\end{array}$ & 6 & $\begin{array}{l}\text { Specify study characteristics (e.g., PICOS, length of follow- } \\
\text { up) and report characteristics (e.g., years considered, } \\
\text { language, publication status) used as criteria for eligibility, } \\
\text { giving rationale. }\end{array}$ & 3 \\
\hline $\begin{array}{l}\text { Information } \\
\text { sources }\end{array}$ & 7 & $\begin{array}{l}\text { Describe all information sources (e.g., databases with dates of } \\
\text { coverage, contact with study authors to identify additional } \\
\text { studies) in the search and date last searched. }\end{array}$ & 3 \\
\hline Search & & $\begin{array}{l}\text { Present full electronic search strategy for at least one } \\
\text { database, including any limits used, such that it could be } \\
\text { repeated. }\end{array}$ & 3 \\
\hline Study selection & 9 & $\begin{array}{l}\text { State the process for selecting studies (i.e., screening, } \\
\text { eligibility, included in systematic review, and, if applicable, } \\
\text { included in the meta-analysis). }\end{array}$ & $\begin{array}{l}3 \\
\text { Table } 2 \\
\text { Figure } 1\end{array}$ \\
\hline $\begin{array}{l}\text { Data collection } \\
\text { process }\end{array}$ & 10 & $\begin{array}{l}\text { Describe method of data extraction from reports (e.g., piloted } \\
\text { forms, independently, in duplicate) and any processes for } \\
\text { obtaining and confirming data from investigators. }\end{array}$ & 3 \\
\hline Data items & 11 & $\begin{array}{l}\text { List and define all variables for which data were sought (e.g., } \\
\text { PICOS, funding sources) and any assumptions and } \\
\text { simplifications made. }\end{array}$ & 3 \\
\hline $\begin{array}{l}\text { Risk of bias in } \\
\text { individual } \\
\text { studies }\end{array}$ & 12 & $\begin{array}{l}\text { Describe methods used for assessing risk of bias of individual } \\
\text { studies (including specification of whether this was done at } \\
\text { the study or outcome level), and how this information is to be } \\
\text { used in any data synthesis. }\end{array}$ & $\begin{array}{l}3 \\
\text { Table } 3-5\end{array}$ \\
\hline
\end{tabular}




\begin{tabular}{|l|c|l|l|}
\hline $\begin{array}{l}\text { Summary } \\
\text { measures }\end{array}$ & 13 & $\begin{array}{l}\text { State the principal summary measures (e.g., risk ratio, } \\
\text { difference in means). }\end{array}$ & $\begin{array}{l}\text { Not } \\
\text { applicable }\end{array}$ \\
\hline $\begin{array}{l}\text { Synthesis of } \\
\text { results }\end{array}$ & 14 & $\begin{array}{l}\text { Describe the methods of handling data and combining results } \\
\text { of studies, if done, including measures of consistency (e.g., } \\
\mathrm{I}^{2} \text { ) for each meta-analysis. }\end{array}$ & $\begin{array}{l}\text { Not } \\
\text { applicable }\end{array}$ \\
\hline
\end{tabular}

\begin{tabular}{|c|c|c|c|}
\hline $\begin{array}{l}\text { Risk of bias } \\
\text { across studies }\end{array}$ & 15 & $\begin{array}{l}\text { Specify any assessment of risk of bias that may affect the } \\
\text { cumulative evidence (e.g., publication bias, selective } \\
\text { reporting within studies). }\end{array}$ & $\begin{array}{l}3 \\
\text { Table 3-5 }\end{array}$ \\
\hline $\begin{array}{l}\text { Additional } \\
\text { analyses }\end{array}$ & 16 & $\begin{array}{l}\text { Describe methods of additional analyses (e.g., sensitivity or } \\
\text { subgroup analyses, meta-regression), if done, indicating } \\
\text { which were pre-specified. }\end{array}$ & Not \\
\hline \multicolumn{4}{|l|}{ RESULTS } \\
\hline Study selection & 17 & $\begin{array}{l}\text { Give numbers of studies screened, assessed for eligibility, } \\
\text { and included in the review, with reasons for exclusions at } \\
\text { each stage, ideally with a flow diagram. }\end{array}$ & $3-4$ \\
\hline $\begin{array}{l}\text { Study } \\
\text { characteristics }\end{array}$ & 18 & $\begin{array}{l}\text { For each study, present characteristics for which data were } \\
\text { extracted (e.g., study size, PICOS, follow-up period) and } \\
\text { provide the citations. }\end{array}$ & \begin{tabular}{|l|}
$4-13$ \\
Table 3-5
\end{tabular} \\
\hline $\begin{array}{l}\text { Risk of bias } \\
\text { within studies }\end{array}$ & 19 & $\begin{array}{l}\text { Present data on risk of bias of each study and, if available, } \\
\text { any outcome level assessment (see item 12). }\end{array}$ & \begin{tabular}{|l|}
$4-13$ \\
Table 3-5
\end{tabular} \\
\hline $\begin{array}{l}\text { Results of } \\
\text { individual studies }\end{array}$ & 20 & $\begin{array}{l}\text { For all outcomes considered (benefits or harms), present, for } \\
\text { each study: (a) simple summary data for each intervention } \\
\text { group (b) effect estimates and confidence intervals, ideally } \\
\text { with a forest plot. }\end{array}$ & Table 3-5 \\
\hline $\begin{array}{l}\text { Synthesis of } \\
\text { results }\end{array}$ & 21 & $\begin{array}{l}\text { Present the main results of the review. If meta-analyses are } \\
\text { done, include for each, confidence intervals and measures of } \\
\text { consistency" in accordance with the text in the Explanation } \\
\text { and Elaboration document. }\end{array}$ & $\begin{array}{l}\text { Not } \\
\text { applicable }\end{array}$ \\
\hline $\begin{array}{l}\text { Risk of bias } \\
\text { across studies }\end{array}$ & 22 & $\begin{array}{l}\text { Present results of any assessment of risk of bias across } \\
\text { studies (see Item 15). }\end{array}$ & Table 3-5 \\
\hline $\begin{array}{l}\text { Additional } \\
\text { analysis }\end{array}$ & 2 & $\begin{array}{l}\text { Give results of additional analyses, if done (e.g., sensitivity } \\
\text { or subgroup analyses, meta-regression [see Item 16]). }\end{array}$ & $\begin{array}{l}\text { Not } \\
\text { applicable }\end{array}$ \\
\hline \multicolumn{4}{|l|}{ DISCUSSION } \\
\hline $\begin{array}{l}\text { Summary of } \\
\text { evidence }\end{array}$ & 24 & $\begin{array}{l}\text { Summarize the main findings including the strength of } \\
\text { evidence for each main outcome; consider their relevance to } \\
\text { key groups (e.g., healthcare providers, users, and policy } \\
\text { makers). }\end{array}$ & $13-15$ \\
\hline Limitations & 25 & $\begin{array}{l}\text { Discuss limitations at study and outcome level (e.g., risk of } \\
\text { bias), and at review-level (e.g., incomplete retrieval of } \\
\text { identified research, reporting bias). }\end{array}$ & 15 \\
\hline Conclusions & 26 & $\begin{array}{l}\text { Provide a general interpretation of the results in the context } \\
\text { of other evidence, and implications for future research. }\end{array}$ & $15-16$ \\
\hline \multicolumn{4}{|l|}{ FUNDING } \\
\hline Funding & 27 & $\begin{array}{l}\text { Describe sources of funding for the systematic review and } \\
\text { other support (e.g., supply of data); role of funders for the }\end{array}$ & 16 \\
\hline
\end{tabular}




\begin{tabular}{|l|l|l|l|}
\hline & & systematic review. & \\
\hline
\end{tabular}

Table 1: PRISMA 2009 Checklist filled out [40].

\begin{tabular}{|c|c|c|}
\hline References & $\begin{array}{l}\text { Excluded/ } \\
\text { included }\end{array}$ & Reason \\
\hline $\begin{array}{l}\text { Omeñaca F, Vázquez L, Garcia-Corbeira P, Mesaros N, Hanssens L et al. } \\
\text { Immunization of preterm infants with GSK's hexavalent combined } \\
\text { diphtheria-tetanus-acellular pertussis-hepatitis B-inactivated poliovirus- } \\
\text { Haemophilus influenzae type b conjugate vaccine: A review of safety and } \\
\text { immunogenicity.Vaccine.2018;36:986-96. }\end{array}$ & Excluded & Review \\
\hline $\begin{array}{l}\text { Ferreira CSM, Perin MCAA, Moraes-Pinto MI, Simão-Gurge RM, Goulart } \\
\text { AL et al. Humoral immune response to measles and varicella vaccination in } \\
\text { former very low birth weight preterm infants. Braz J Infect Dis.2018;22:41-6. } \\
\text { [64] }\end{array}$ & $\begin{array}{c}\text { Included } \\
\text { (immunogenicity) }\end{array}$ & \\
\hline $\begin{array}{l}\text { Sisson H, Gardiner E, Watson R. Vaccination timeliness in preterm infants: } \\
\text { An integrative review of the literature. J Clin Nurs.2017:26;4094-104. }\end{array}$ & Excluded & iew \\
\hline $\begin{array}{l}\text { Cuna A, Winter L. Quality Improvement Project to Reduce Delayed } \\
\text { Vaccinations in Preterm Infants. Adv Neonatal Care.2017;17:245-49. }\end{array}$ & Excluded & Not pertinent \\
\hline $\begin{array}{l}\text { Wilińska M, Warakomska M, Głuszczak-Idziakowska E, Jackowska T. Risk } \\
\text { factors for adverse events after vaccinations performed during the initial } \\
\text { hospitalization of infants born prematurely. Dev Period Med.2016;20:296- } \\
\text { 305. [55[ }\end{array}$ & & \\
\hline $\begin{array}{l}\text { Martinón-Torres F, Wysocki J, Center KJ, Czajka H, Majda-Stanislawska E, } \\
\text { et al. Circulating Antibody } 1 \text { and } 2 \text { Years After Vaccination With the 13- } \\
\text { Valent Pneumococcal Conjugate Vaccine in Preterm Compared With Term } \\
\text { Infants. Pediatr Infect Dis J.2017;36:326-32. [67] }\end{array}$ & $\begin{array}{c}\text { Included } \\
\text { (immunogenicity) }\end{array}$ & \\
\hline $\begin{array}{l}\text { Kucukoglu S, Aytekin A, Celebioglu A, Celebi A, Caner I, et al. Effect of } \\
\text { White Noise in Relieving Vaccination Pain in Premature Infants. Pain Manag } \\
\text { Nurs.2016;17:392-400. }\end{array}$ & Excluded & Not pertinent \\
\hline $\begin{array}{l}\text { Kent A, Ladhani SN, Andrews NJ, Scorrer T, Pollard AJ, et al. Schedules for } \\
\text { Pneumococcal Vaccination of Preterm Infants: An RCT. } \\
\text { Pediatrics.2016;138:e20153945-58[49] }\end{array}$ & $\begin{array}{l}\text { Included } \\
\text { (immunogenicity } \\
\text { and safety) }\end{array}$ & \\
\hline $\begin{array}{l}\text { Kilich E, Sadarangani M. Use of rotavirus vaccines in preterm babies on the } \\
\text { neonatal unit. Expert Rev Vaccines.2016;15:1463-65. }\end{array}$ & Excluded & Not pertinent \\
\hline $\begin{array}{l}\text { Kjærgaard J, Stensballe LG, Birk NM, Nissen TN, Thøstesen LM, et al. } \\
\text { Bacillus Calmette-Guérin vaccination at birth: Effects on infant growth. A } \\
\text { randomized clinical trial. Early Hum Dev.2016;100:49-54 [43] }\end{array}$ & $\begin{array}{l}\text { Included } \\
\text { (safety) }\end{array}$ & \\
\hline $\begin{array}{l}\text { Higgins RD, Shankaran S. The Neonatal Research Network: History since } \\
\text { 2003, future directions and challenges. Semin Perinatol.2016;40:337-40. }\end{array}$ & Excluded & Not pertinent \\
\hline $\begin{array}{l}\text { Olsen SJ, Mirza SA, Vonglokham P, Khanthamaly V, Chitry B et al. The } \\
\text { Effect of Influenza Vaccination on Birth Outcomes in a Cohort of Pregnant } \\
\text { Women in Lao PDR, 2014-2015. Clin Infect Dis.2016;63:487-94. }\end{array}$ & Excluded & Not pertinent \\
\hline $\begin{array}{l}\text { Kjærgaard J, Stensballe LG, Birk NM, Nissen TN, Foss KT et al. Lack of a } \\
\text { Negative Effect of BCG-Vaccination on Child Psychomotor Development: } \\
\text { Results from the Danish Calmette Study - A Randomised Clinical Trial. } \\
\text { PLoS One.2016;11:e0154541. [44] }\end{array}$ & $\begin{array}{c}\text { Included } \\
\text { (safety) }\end{array}$ & \\
\hline $\begin{array}{l}\text { Navarro-Alonso JA, Taboada-Rodríguez JA, Limia-Sánchez A; Toward a } \\
\text { New Immunization Schedule in Spain, } 2016 \text { (Part 2). Rev Esp Salud } \\
\text { Publica.2016;90:E3. }\end{array}$ & Excluded & Review \\
\hline $\begin{array}{l}\text { McArdle AJ, Mugisha G, Birahinduka D. QUESTION 2: Vaccinating } \\
\text { preterm infants in resource-poor settings: what is the incidence of apnoea, } \\
\text { bradycardia and need for respiratory support? Arch Dis Child 2016;101:290- } \\
\text { 3. }\end{array}$ & Excluded & Commentary \\
\hline $\begin{array}{l}\text { Salamouras D, Levy J. Vaccination of premature infants, a population at high } \\
\text { risk of infection. Rev Med Brux.2015;36:223-8 }\end{array}$ & Excluded & Review in French \\
\hline $\begin{array}{l}\text { Saroha M, Faridi MM, Batra P, Kaur I, Dewan DK. Immunogenicity and } \\
\text { safety of early vs delayed BCG vaccination in moderately preterm (31-33 } \\
\text { weeks) infants. Hum Vaccin Immunother.2015;11:2864-71 [42] }\end{array}$ & $\begin{array}{l}\text { Included } \\
\text { (safety and } \\
\text { immunogenicity) }\end{array}$ & \\
\hline $\begin{array}{l}\text { McCrossan P, McCafferty C, Murphy C, Murphy J. Retrospective review of } \\
\text { administration of childhood primary vaccination schedule in an Irish tertiary } \\
\text { neonatal intensive care unit. Public Health.2015;129:896-8. }\end{array}$ & $\begin{array}{c}\text { Included } \\
\text { (safety) }\end{array}$ & \\
\hline
\end{tabular}




\begin{tabular}{|c|c|c|}
\hline $\begin{array}{l}\text { Kilich E, Anthony M. Rotavirus vaccination in preterm infants: a neonatal } \\
\text { guidance chart to aid timely immunisation. Arch Dis Child Fetal Neonatal } \\
\text { Ed.2015;100:F465. }\end{array}$ & Excluded & Letter \\
\hline $\begin{array}{l}\text { Mehler K, Ulbrich L, Börner S, Joachim A, Becker I, et al. Multidimensional } \\
\text { response to vaccination pain in very preterm, moderate- to-late preterm and } \\
\text { full-term infants at age three months. Early Hum Dev.2015;91:199-204 }\end{array}$ & Excluded & Not pertinet \\
\hline $\begin{array}{l}\text { Ochoa TJ, Zea-Vera A, Bautista R, Davila C, Salazar JA et al. Vaccine } \\
\text { schedule compliance among very low birth weight infants in Lima, Peru. } \\
\text { Vaccine.2015;33:354-8. }\end{array}$ & Excluded & Not pertinent \\
\hline $\begin{array}{l}\text { Czajka H, Lauterbach R, Pawlik D. Vaccination of preterm infants by } \\
\text { polyvalent vaccines: immunogenicity and safety- review of literature. Dev } \\
\text { Period Med.2014;18:360-6 }\end{array}$ & Excluded & Review \\
\hline $\begin{array}{l}\text { Erener-Ercan T, Aslan M, Vural M, Erginoz E, Kocazeybek B et al. Tetanus } \\
\text { and diphtheria immunity among term and preterm infant-mother pairs in } \\
\text { Turkey, a country where maternal and neonatal tetanus have recently been } \\
\text { eliminated. Eur J Pediatr.2014;174:339-44 }\end{array}$ & Excluded & Not pertinent \\
\hline $\begin{array}{l}\text { Tozzi AE, Piga S, Corchia C, Di Lallo D, Carnielli V et al. Timeliness of } \\
\text { routine immunization in a population-based Italian cohort of very preterm } \\
\text { infants: results of the ACTION follow-up project. Vaccine.2014;32:793-9. }\end{array}$ & Excluded & tinent \\
\hline $\begin{array}{l}\text { Woestenberg PJ, van Lier A, van der Maas NA, Drijfhout IH, Oomen PJ et al. } \\
\text { Delayed start of diphtheria, tetanus, acellular pertussis and inactivated polio } \\
\text { vaccination in preterm and low birth weight infants in the Netherlands. } \\
\text { Pediatr Infect Dis J.2014;33:190-8. }\end{array}$ & Excluded & ient \\
\hline $\begin{array}{l}\text { Szynczewska E, Chlebna-Sokół D. Immunogenicity of heptavalent conjugate } \\
\text { vaccine against Streptococcus pneumoniae in premature babies with low birth } \\
\text { weight. Pediatr Neonatol.2014 Apr;55(2):101-7 [65] }\end{array}$ & $\begin{array}{c}\text { Included } \\
\text { (immunogenicity) }\end{array}$ & \\
\hline $\begin{array}{l}\text { Shen S, Campitelli MA, Calzavara A, Guttmann A, Kwong JC. Seasonal } \\
\text { influenza vaccine effectiveness in pre- and full-term children aged 6-23 } \\
\text { months over multiple seasons. Vaccine.2013;31:2974-8 [69] }\end{array}$ & $\begin{array}{r}\text { Inc } \\
(\mathrm{effec}\end{array}$ & $\gamma$ \\
\hline $\begin{array}{l}\text { Wilson K, Hawken S, Holdt Henningsen K, Kwong JC, Deeks SL et al. On- } \\
\text { time vaccination coverage in premature infants in Ontario, 2002-2009. Can J } \\
\text { Public Health.2012;10:e359-62 }\end{array}$ & & Not pertinent \\
\hline $\begin{array}{l}\text { Vermeulen F, Dirix V, Verscheure V, Damis E, Vermeylen D, et al. } \\
\text { Persistence at one year of age of antigen-induced cellular immune responses } \\
\text { in preterm infants vaccinated against whooping cough: comparison of three } \\
\text { different vaccines and effect of a booster dose. Vaccine.2013;31:1981-6 [70] }\end{array}$ & $\begin{array}{l}\text { Included } \\
\text { (immunogenicity) }\end{array}$ & \\
\hline $\begin{array}{l}\text { Ichikawa T, Tsuji A, Fujino M, Kusano R, Sugiyama R et al. Effect of early } \\
\text { measles vaccination (AIK-C strain) for preterm infants. Pediatr } \\
\text { Int.2013;55:163-8. }\end{array}$ & $\begin{array}{l}\text { Included (safety } \\
\quad \text { and } \\
\text { immunogenicity) }\end{array}$ & \\
\hline $\begin{array}{l}\text { Esposito S, Fumagalli M, Principi N. Immunogenicity, safety and tolerability } \\
\text { of vaccinations in premature infants. Expert Rev Vaccines.2012;11:1199- } \\
209 .\end{array}$ & Excluded & Review \\
\hline $\begin{array}{l}\text { Ahrens K, Lash TL, Louik C, Mitchell AA, Werler MM. Correcting for } \\
\text { exposure misclassification using survival analysis with a time-varying } \\
\text { exposure. Ann Epidemiol.2012;22:799-806 }\end{array}$ & Excluded & Not pertinent \\
\hline $\begin{array}{l}\text { Wilson K, Hawken S. Incidence of adverse events in premature children } \\
\text { following 2-month vaccination. Hum Vaccin Immunother.2012;8:592-5 [52] }\end{array}$ & Included (safety) & \\
\hline $\begin{array}{l}\text { Zhang L, Zhai XJ, Li YP, Zhang W, Zhu FC, Huang T, et al. Multi-center } \\
\text { matching study on antibody response between preterm and full-term infants } \\
\text { after primary immunization of hepatitis B vaccine. Zhonghua Liu Xing Bing } \\
\text { Xue Za Zhi.2012;33:185-8. }\end{array}$ & Excluded & $\begin{array}{l}\text { Not written in } \\
\text { english }\end{array}$ \\
\hline $\begin{array}{l}\text { Meinus C, Schmalisch G, Hartenstein S, Proquitté H, Roehr CC. Adverse } \\
\text { cardiorespiratory events following primary vaccination of very low birth } \\
\text { weight infants. J Pediatr (Rio J). } 2012 \text { Mar-Apr;88(2):137-42 }\end{array}$ & Excluded & $\begin{array}{l}\text { Not written in } \\
\text { english }\end{array}$ \\
\hline $\begin{array}{l}\text { Gaudelus J, Lachassinne E, de Pontual L. Immunization of the preterm } \\
\text { infant. Rev Prat.2012;62:382-3 }\end{array}$ & Excluded & $\begin{array}{l}\text { Not written in } \\
\text { english }\end{array}$ \\
\hline $\begin{array}{l}\text { Lin TH, Lin SY, Lin CH, Lin RI, Lin HC et al. AdimFlu-S(®) influenza A } \\
\text { (H1N1) vaccine during pregnancy: the Taiwanese Pharmacovigilance Survey. } \\
\text { Vaccine.2012 Mar 30;30(16):2671-5. }\end{array}$ & Excluded & Not pertinent \\
\hline $\begin{array}{l}\text { Buijs SC, Boersma B. Cardiorespiratory events after first immunization in } \\
\text { premature infants: a prospective cohort study]. Ned Tijdschr } \\
\text { Geneeskd.2012;156:A3797. }\end{array}$ & Excluded & $\begin{array}{l}\text { Not written in } \\
\text { english }\end{array}$ \\
\hline $\begin{array}{l}\text { Omenaca F, Sarlangue J, Szenborn L, Nogueira M, Suryakiran PV, et al. } \\
\text { Safety, reactogenicity and immunogenicity of the human rotavirus vaccine in } \\
\text { preterm European Infants: a randomized phase IIIb study. Pediatr Infect Dis } \\
\text { J.2012;31:487-93 }\end{array}$ & $\begin{array}{l}\text { Included (safety } \\
\quad \text { and } \\
\text { immunogenicity) }\end{array}$ & \\
\hline $\begin{array}{l}\text { Tsuda K, Iwasaki S, Horiguchi H, Mori M, Nishimaki S, et al. Immune } \\
\text { response to Haemophilus influenzae type b conjugate vaccine in preterm } \\
\text { infants. Pediatr Int. 2012;54:64-7 [47] }\end{array}$ & $\begin{array}{l}\text { Included (safety } \\
\quad \text { and } \\
\text { immunogenicity) }\end{array}$ & \\
\hline $\begin{array}{l}\text { Mullooly JP, Schuler R, Mesa J, Drew L, DeStefano F et al. Wheezing lower } \\
\text { respiratory disease and vaccination of premature infants. }\end{array}$ & Excluded & Not pertinent \\
\hline
\end{tabular}




\begin{tabular}{|c|c|c|}
\hline Vaccine.2011;29:7611-7 & & \\
\hline $\begin{array}{l}\text { Omeñaca F, Arístegui J, Tejedor JC, Moreno-Perez D, Ruiz-Contreras J et al. } \\
\text { Combined Haemophilus Influenzae type B-Neisseria meningitidis serogroup } \\
\text { C vaccine is immunogenic and well tolerated in preterm infants when } \\
\text { coadministered with other routinely recommended vaccines. Pediatr Infect } \\
\text { Dis J.2011;30:e216-24 [53] }\end{array}$ & $\begin{array}{l}\text { Included (safety } \\
\quad \text { and } \\
\text { immunogenicity) }\end{array}$ & \\
\hline $\begin{array}{l}\text { Omeñaca F, Merino JM, Tejedor JC, Constantopoulos A, Papaevangelou V, } \\
\text { Kafetzis D. Immunization of preterm infants with 10-valent pneumococcal } \\
\text { conjugate vaccine. Pediatrics } 2011 ; 128: \mathrm{e} 290-8 \text { [54] }\end{array}$ & $\begin{array}{l}\text { Included (safety } \\
\quad \text { and } \\
\text { immunogenicity) }\end{array}$ & \\
\hline $\begin{array}{l}\text { Calderón C G, Moore V R, Pittaluga P E, Potin S M. Adherence to } \\
\text { immunizations in newborns less than } 1500 \text { gr at birth and/or younger than } 32 \\
\text { weeks, in two chilean centers. Rev Chilena Infectol.2011;28:166-73 }\end{array}$ & Excluded & $\begin{array}{l}\text { Not written in } \\
\text { english }\end{array}$ \\
\hline $\begin{array}{l}\text { Clifford V, Crawford NW, Royle J, Lazzaro T, Danchin M, et al. Recurrent } \\
\text { apnoea post immunisation: Informing re-immunisation policy. } \\
\text { Vaccine.2011;29:5681-7. [33] }\end{array}$ & Included (safety) & \\
\hline $\begin{array}{l}\text { Esposito S, Pugni L, Daleno C, Ronchi A, Valzano A et al. Influenza } \\
\text { A/H1N1 MF59-adjuvanted vaccine in preterm and term children aged } 6 \text { to } 23 \\
\text { months. Pediatrics.2011 May;127:e1161-8. [48] }\end{array}$ & $\begin{array}{l}\text { Included (safety } \\
\text { and } \\
\text { immunogenicity) }\end{array}$ & \\
\hline $\begin{array}{l}\text { Zanoni G, Gottin L, Boner A, Piacentini G, Peroni D et al. Case discussion of } \\
\text { an immediate serious reaction to hexavalent vaccine mistaken for } \\
\text { anaphylaxis. Br J Clin Pharmacol.2010;70:916-7. }\end{array}$ & Excluded & Cas \\
\hline $\begin{array}{l}\text { Mirpuri J, Jain L. Issues of prematurity and HIV infection. Clin } \\
\text { Perinatol.2010;37:887-905 }\end{array}$ & Excluded & Not \\
\hline Baxter D. Premature infants and vaccination. Hum Vaccin.2010;6:493. & Excluded & Comment on \\
\hline $\begin{array}{l}\text { Trück J, Pollard AJ. Challenges in immunisation against bacterial infection in } \\
\text { children. Early Hum Dev.2010;86:695-701. }\end{array}$ & Excluded & Not pertinent \\
\hline $\begin{array}{l}\text { Dhillon S. Spotlight on DTPa-HBV-IPV/Hib Vaccine (Infanrix hexa). } \\
\text { BioDrugs.2010;24:299-302 }\end{array}$ & Excluc & Review \\
\hline $\begin{array}{l}\text { Baxter D. Vaccine responsiveness in premature infants. Hum } \\
\text { Vaccin.2010;6:506-11 }\end{array}$ & & Review \\
\hline $\begin{array}{l}\text { Baxter D. Impaired functioning of immune defenses to infection in premature } \\
\text { and term infants and their implications for vaccination. Hum } \\
\text { Vaccin.2010;6:494-505. }\end{array}$ & luded & Review \\
\hline $\begin{array}{l}\text { Tinnion RJ, Berrington JE. Flu vaccination for ex-preterms and infants under } \\
6 \text { months--are we getting it right? Arch Dis Child.2010 May;95:400-1 }\end{array}$ & Excluded & Letter \\
\hline $\begin{array}{l}\text { Baxter D, Ghebrehewet S, Welfare W, Ding DC. Vaccinating premature } \\
\text { infants in a Special Care Baby Unit in the UK: results of a prospective, non- } \\
\text { inferiority based, pragmatic case series study. Hum Vaccin.2010;6:512-20. }\end{array}$ & $\begin{array}{l}\text { Included } \\
\text { (immunogenicity) }\end{array}$ & \\
\hline $\begin{array}{l}\text { Pinquier D, Adde-Michela C, Ploin D, Levêque C, Marret S; Vaccination rate } \\
\text { of premature infants at } 6 \text { and } 24 \text { months of age: a pilot study. Arch } \\
\text { Pediatr.2009 Dec;16:1533-9. }\end{array}$ & Excluded & $\begin{array}{l}\text { Not written in } \\
\text { english }\end{array}$ \\
\hline $\begin{array}{l}\text { Esposito S, Serra D, Gualtieri L, Cesati L, Principi N. Vaccines and preterm } \\
\text { neonates: why, when, and with what. Early Hum Dev 2009;85:S43-5. }\end{array}$ & Excluded & Review \\
\hline $\begin{array}{l}\text { Fleischer L, Syed SS. Hepatitis B surface antigenemia in a neonate following } \\
\text { vaccination with Pediarix. Clin Pediatr.2009;4:311-2. }\end{array}$ & Excluded & Case report \\
\hline $\begin{array}{l}\text { Ryan MA, Gumbs GR, Conlin AM, Sevick CJ, Jacobson IG et al. Evaluation } \\
\text { of preterm births and birth defects in liveborn infants of US military women } \\
\text { who received smallpox vaccine. Birth Defects Res A Clin Mol } \\
\text { Teratol.2008;82:533-9 }\end{array}$ & Excluded & Not pertinent \\
\hline $\begin{array}{l}\text { Klein NP, Massolo ML, Greene J, Dekker CL, Black S et al. Risk factors for } \\
\text { developing apnea after immunization in the neonatal intensive care unit. } \\
\text { Pediatrics.2008;121:463-9 [60] }\end{array}$ & Included (safety) & \\
\hline
\end{tabular}

Table 2: Sixty-one articles identified with the search details (infant, preterm"[MeSH Terms]) AND

"vaccination"[MeSH terms] and exclusion criteria for the screening relying on studies' abstracts or titles.

\begin{tabular}{|c|c|c|c|c|c|c|c|c|c|}
\hline $\begin{array}{l}\begin{array}{l}\text { Author } \\
\text { (year) }\end{array}\end{array}$ & Design & No of pts & $\begin{array}{l}\text { Gestatio } \\
\text { nal Age } \\
\text { in } \\
\text { weeks } \\
\text { (w) }\end{array}$ & Location & Vaccine & Objectives & $\begin{array}{l}\text { Follow } \\
\text { up (FU) } \\
\text { after } \\
\text { vaccine }\end{array}$ & Results & Bias \\
\hline $\begin{array}{l}\text { Ben Jmaa } \\
\text { et al. } \\
(2017) 62\end{array}$ & $\begin{array}{l}\text { Prospective } \\
\text { randomized, } \\
\text { double } \\
\text { blinded, } \\
\text { placebo- } \\
\text { controlled }\end{array}$ & 56 & $<32 \mathrm{w}$ & Canada & $\begin{array}{l}\text { DTPa,IPV, } \\
\text { Hib, } \\
\text { PCV10 }\end{array}$ & $\begin{array}{l}\text { To analyze cardio- } \\
\text { respiratory Events (CREs) } \\
48 \text { hours after vaccination } \\
\text { and inflammatory } \\
\text { eesponse after primary } \\
\text { Immunization }\end{array}$ & $48 \mathrm{~h}$ & $\begin{array}{l}\text {-Significant correlation between } \Delta \mathrm{C} \text { - } \\
\text { reactive protein and } \Delta \text { Total } \\
\mathrm{CRE} / \text { patient } / 24 \text { hours; } \\
\text {-CRE/patient } / 24 \text { hours was } \\
\text { unchanged before versus after } \\
\text { immunization }(6.7 \pm 7.7 \text { before } \\
\text { versus } 6.8 \pm 9.7 \text { after, } \mathrm{P}=0.9) \text { in the } \\
\text { ibuprofen group }\end{array}$ & \\
\hline
\end{tabular}




\begin{tabular}{|c|c|c|c|c|c|c|c|c|c|}
\hline $\begin{array}{l}\text { Kjærgaard } \\
\text { et al. } \\
(2016) 43\end{array}$ & $\begin{array}{l}\text { Prospective } \\
\text { randomized, } \\
\text { multicenter } \\
\text { clinical trial }\end{array}$ & $\begin{array}{l}4262 \\
(144 \text { born } \\
32-37 \mathrm{w})\end{array}$ & $32-37 \mathrm{w}$ & Denmark & BCG & $\begin{array}{l}\text { Effects of } r \text { BCG } \\
\text { vaccination on early } \\
\text { childhood infections, } \\
\text { growth and development } \\
\text { in term and preterm infant }\end{array}$ & $\begin{array}{l}22 \\
\text { months }\end{array}$ & $\begin{array}{l}\text { There was no effect of BCG on } \\
\text { either incidence of infections, } \\
\text { growth, body composition or } \\
\text { psychomotor development }\end{array}$ & \\
\hline $\begin{array}{l}\text { Kjærgaard } \\
\text { et al. } \\
(2016) 44\end{array}$ & $\begin{array}{l}\text { Prospective } \\
\text { randomized, } \\
\text { multicenter } \\
\text { clinical trial }\end{array}$ & $\begin{array}{l}4262 \\
(144 \text { born } \\
32-37 \mathrm{w})\end{array}$ & $32-37 \mathrm{w}$ & Denmark & BCG & $\begin{array}{l}\text { To assess the non-specific } \\
\text { effect of Bacillus } \\
\text { Calmette-Guérin (BCG) } \\
\text { vaccination at birth on } \\
\text { psychomotor development }\end{array}$ & $\begin{array}{l}22 \\
\text { months }\end{array}$ & $\begin{array}{l}\text { Lack of a Negative Effect of BCG- } \\
\text { Vaccination on Child Psychomotor } \\
\text { Development }\end{array}$ & \\
\hline $\begin{array}{l}\text { Kent et al } \\
(2016) 49\end{array}$ & $\begin{array}{l}\text { Phase IV, } \\
\text { open-label, } \\
\text { prospective, } \\
\text { multicenter, } \\
\text { randomized } \\
\text { controlled } \\
\text { trial }\end{array}$ & 199 & $<35 \mathrm{w}$ & UK & $\begin{array}{l}\text { PCV13 in } \\
\text { association } \\
\text { with other } \\
\text { polyvalent } \\
\text { vaccines }\end{array}$ & $\begin{array}{l}\text { To evaluate solicited } \\
\text { adverse events (AEs) }\end{array}$ & 28 days & $\begin{array}{l}\text { - no significant differences in the } \\
\text { frequency or severity of local and } \\
\text { systemic AEs between vaccination } \\
\text { schedules at any time point } \\
\text { - } 77 \text { serious AEs, of which } 1 \\
\text { possibly related to vaccination } \\
\text { unexpected serious adverse reaction } \\
\text { from each randomized group }\end{array}$ & \\
\hline $\begin{array}{l}\text { Wilińska et } \\
\text { al (2016) } 55\end{array}$ & $\begin{array}{l}\text { Observational } \\
\text { prospective }\end{array}$ & 138 & $\begin{array}{l}73 \leq 28 \\
w \\
65>28 \\
w\end{array}$ & Poland & $\begin{array}{l}\text { DTPa-IPV- } \\
\text { HBV-Hib- } \\
\text { PCV }\end{array}$ & $\begin{array}{l}\text { To assess incidence of } \\
\text { adverse events following } \\
\text { vaccination (AEFV) } \\
\text { monitoring cardio- } \\
\text { respiratory functions and } \\
\text { body temperature }\end{array}$ & 72 hours & $\begin{array}{l}\text { - Apnea and activity dysfunctions } \\
\text { were the relatively most frequent } \\
\text { AEFI. } \\
\text {-Preterm newborns who experienced } \\
\text { apnea show significantly more } \\
\text { frequent late onset sepsis }(\mathrm{p}=0.028) \\
\text { as well as a history of longer use of } \\
\text { continuous positive air pressure } \\
\text { (CPAP) } \mathrm{p}=0.033)\end{array}$ & $\begin{array}{l}\text {-no control } \\
\text { group } \\
\text {-small } \\
\text { sample size }\end{array}$ \\
\hline $\begin{array}{l}\text { De Meo et } \\
\text { al (2015) } 58\end{array}$ & $\begin{array}{l}\text { Multicenter } \\
\text { retrospective } \\
\text { cohort study }\end{array}$ & 13,926 & $\leq 28 \mathrm{w}$ & USA & $\begin{array}{l}\text { DTPa, } \\
\text { IPV, HBV, } \\
\text { Hib, PCV7 }\end{array}$ & $\begin{array}{l}\text { To assess sepsis evaluation } \\
\text { (collection of blood } \\
\text { culture), need of increased } \\
\text { respiratory support, } \\
\text { seizures and death in the } 3 \\
\text { days following vaccination }\end{array}$ & 3 days & $\begin{array}{l}\text {-The incidence of sepsis evaluation } \\
\text { and increased respiratory support } \\
\text { increase from the pre-immunization } \\
\text { period to the post-immunization } \\
\text { period } \\
\text {-Infants } 23-24 \text { weeks of gestation } \\
\text { demonstrated an increased incidence } \\
\text { of sepsis evaluation and increased } \\
\text { respiratory support compared to } \\
\text { older infants (27- } 28 \text { weeks } \\
\text { gestation) } \\
\text {-A prior history of gram-positive } \\
\text { sepsis was associated with an } \\
\text { increased rate for sepsis evaluation in } \\
\text { the post-immunization period. } \\
\text {-There was no difference in the } \\
\text { incidence of adverse events in } \\
\text { combination vaccines versus single- } \\
\text { dose vaccines. }\end{array}$ & $\begin{array}{l}\text {-"healthy } \\
\text { vaccinated } \\
\text { "effect } \\
\text {-physicians } \\
\text { may be } \\
\text { more likely } \\
\text { to } \\
\text { document } \\
\text { adverse } \\
\text { events that } \\
\text { are } \\
\text { occurring } \\
\text { in close } \\
\text { proximity } \\
\text { to the } \\
\text { administrat } \\
\text { ion of } \\
\text { immunizati } \\
\text { ons }\end{array}$ \\
\hline $\begin{array}{l}\text { McCrossan } \\
\text { et al (2015) } \\
51\end{array}$ & Retrospective & 344 & $<37 \mathrm{w}$ & Ireland & $\begin{array}{l}\text { DTPa, } \\
\text { IPV, HBV, } \\
\text { PCV, Hib }\end{array}$ & $\begin{array}{l}\text { To assess delay in } \\
\text { administration and safety } \\
\text { of vaccines in preterm }\end{array}$ & & $\begin{array}{l}\text { None of the patients had a } \\
\text { documented adverse reaction }\end{array}$ & $\begin{array}{l}- \\
\text { Retrospecti } \\
\text { ve study } \\
\text {-not clear } \\
\text { the period } \\
\text { of follow } \\
\text { up }\end{array}$ \\
\hline $\begin{array}{l}\text { Saroha et al } \\
(2015) 42\end{array}$ & $\begin{array}{l}\text { Prospective } \\
\text { randomized } \\
\text { comparative } \\
\text { trial }\end{array}$ & 117 & $31-33 \mathrm{w}$ & & BCG & $\begin{array}{l}\text { To compare complications } \\
\text { of BCG vaccine in preterm } \\
\text { infants aged } 31-33 \text { weeks } \\
\text { immunized at birth or at } \\
34 \text { completed weeks }\end{array}$ & $\begin{array}{l}6 \\
\text { months }\end{array}$ & $\begin{array}{l}\text {-Left axillary lymphadenopathy was } \\
\text { the only complication seen in } 3.4 \% \\
\text { of patients in in both groups } \\
\text {-BCG vaccine may be safely given to } \\
\text { moderately preterm infants (31-33 } \\
\text { weeks) at birth }\end{array}$ & \\
\hline $\begin{array}{l}\text { Roué et al } \\
(2014) 45\end{array}$ & $\begin{array}{l}\text { Population- } \\
\text { based study }\end{array}$ & 7150 & $\begin{array}{l}6883>37 \\
\text { W } \\
267<37 \\
\text { W }\end{array}$ & France & $\begin{array}{l}\text { Rotavirus } \\
\text { vaccine }\end{array}$ & $\begin{array}{l}\text { To analyze the cause of } \\
\text { hospitalizations for up to } \\
42 \text { days after the last dose } \\
\text { of Rotavirus vaccine }\end{array}$ & 42 days & $\begin{array}{l}\text {-No significant differences in severe } \\
\text { AEs following vaccination between } \\
\text { premature and term infants were } \\
\text { found }(5.2 \% \text { versus } 8.1 \%, p=0.09) \\
\text {-No case of intussusception nor of } \\
\text { Kawasaki disease were reported. }\end{array}$ & \\
\hline $\begin{array}{l}\text { Ichikawa et } \\
\text { al (2013) } 41\end{array}$ & Prospective & 17 & $<34 \mathrm{w}$ & Japan & $\begin{array}{l}\text { Measles } \\
\text { vaccine }\end{array}$ & $\begin{array}{lr}\text { To } & \text { evaluate } \\
\text { immunogenicity } \quad \text { and } \\
\text { safety of early vaccination } \\
\text { with measles vaccine at } 6 \\
\text { months. }\end{array}$ & $\begin{array}{l}12 \\
\text { months } \\
\text { after } \\
\text { birth }\end{array}$ & AEs did not occur & $\begin{array}{l}\text { Small } \\
\text { sample }\end{array}$ \\
\hline $\begin{array}{l}\text { Anderson } \\
\text { et al (2012) } \\
56\end{array}$ & Retrospective & 203 & $\leq 28 \mathrm{w}$ & Australia & $\begin{array}{l}\text { DTaP, } \\
\text { IPV, Hib, } \\
\text { PCV }\end{array}$ & $\begin{array}{l}\text { To evaluate likely/possible } \\
\text { apneic reaction within } 48 \\
\text { hours following } 2 \text { months } \\
\text { vaccination }\end{array}$ & $48 \mathrm{~h}$ & $\begin{array}{l}\text {-18 preterm infants had a vaccine } \\
\text { reaction, } 17 \text { with likely/possible } \\
\text { apnea reaction (incidence } 8,4 \% \text { ) after } \\
2 \text { months vaccination } \\
\text {-Babies reacting to the } 2 \text {-month } \\
\text { vaccine were statistically of lower } \\
\text { birth gestation and birth weight } \\
\text { - There were no reactions to the } \\
\text { following vaccine doses }\end{array}$ & $\begin{array}{l}\text {-Small case } \\
\text { numbers } \\
\text {-lack of } \\
\text { cardiorespi } \\
\text { ratory } \\
\text { monitoring } \\
\text { for the 4- } \\
\text { month } \\
\text { immunizati } \\
\text { ons in } \\
\text { approximat } \\
\text { ely } 50 \% \text { of }\end{array}$ \\
\hline
\end{tabular}




\begin{tabular}{|c|c|c|c|c|c|c|c|c|c|}
\hline & & & & & & & & & cases \\
\hline $\begin{array}{l}\text { Omenaca et } \\
\text { al (2012) } 46\end{array}$ & $\begin{array}{l}\text { randomized } \\
\text { double } \\
\text { blinded } \\
\text { placebo- } \\
\text { controlled } \\
\text { trial }\end{array}$ & 250 & $\begin{array}{l}\geq 27 \text { and } \\
<37 \mathrm{w}\end{array}$ & $\begin{array}{l}\text { France, } \\
\text { Portugal, } \\
\text { Poland, } \\
\text { Spain }\end{array}$ & $\begin{array}{l}\text { Rotavirus } \\
\text { vaccine }\end{array}$ & $\begin{array}{l}\text { To assess the occurrence } \\
\text { of any solicited and } \\
\text { unsolicited AEs during the } \\
15 \text { - and 31-day } \\
\text { postvaccination follow-up } \\
\text { period after each dose, } \\
\text { respectively and severe } \\
\text { adverse event (SAE) }\end{array}$ & 31 days & $\begin{array}{l}\text { - Frequency of AEs recorded in the } \\
\text { vaccine and placebo groups were } \\
\text { similar }(\mathrm{P}=0.266) \text {. } \\
\text {-During the } 31 \text {-day postvaccination } \\
\text { follow-up period, at least } 1 \\
\text { unsolicited AE was reported in } 196 \\
(29.3 \%, 95 \% \text { CI: } 25.8-32.9 \%) \text { and } \\
138(40.7 \%, 95 \% \text { CI: } 35.4-46.1 \%) \\
\text { infants in the vaccine and placebo } \\
\text { groups, respectively (P }<0.05) \text {. } \\
\text { - The percentage of all and grade } 3 \\
\text { solicited general AEs recorded } \\
\text { during the } 15 \text {-day postvaccination } \\
\text { follow-up period were similar in both } \\
\text { groups (P > } 0.05) \text { with irritability } \\
\text { being the most common AE reported }\end{array}$ & $\begin{array}{l}\text { - } \\
\text { coadminist } \\
\text { ration of } \\
\text { other } \\
\text { polyvalent } \\
\text { vaccines }\end{array}$ \\
\hline $\begin{array}{l}\text { Tsuda et al } \\
\text { (2012) } 47\end{array}$ & $\begin{array}{l}\text { prospective } \\
\text { cohort study }\end{array}$ & $\begin{array}{l}54 \text { preterm } \\
\text { infants }\end{array}$ & $<37 w$ & Japan & $\mathrm{Hib}$ & $\begin{array}{l}\text { To assess immunogenicity } \\
\text { and side-effects after } \\
\text { vaccination }\end{array}$ & & $\begin{array}{l}\text {-Side-effects after vaccination were } \\
\text { rare, with only one case of local } \\
\text { redness }\end{array}$ & $\begin{array}{l}\text {-small } \\
\text { number of } \\
\text { samples } \\
\text {-not clear } \\
\text { the follow } \\
\text { up period }\end{array}$ \\
\hline $\begin{array}{l}\text { Wilson et al } \\
(2012) 52\end{array}$ & $\begin{array}{l}\text { Retrospective } \\
\text { self- } \\
\text { controlled } \\
\text { case-series }\end{array}$ & 771453 & $\begin{array}{l}-49220 \\
\text { born } 33- \\
36 \mathrm{w} \\
-7392 \\
\text { born } \leq \\
32 \mathrm{w}\end{array}$ & Canada & $\begin{array}{l}\text { DTPa-IPV- } \\
\text { HiB-PCV }\end{array}$ & $\begin{array}{l}\text {-to evaluate rates of } \\
\text { emergency room visits and } \\
\text { hospital admissions within } \\
3 \text { days following } 2 \text { months } \\
\text { vaccination }\end{array}$ & 3 days & $\begin{array}{l}\text {-Reduced AEs (as emergency room } \\
\text { visits and hospital admission) were } \\
\text { obseryed in preterm infants when } \\
\text { compared to small for gestational age } \\
\text { term children. When compared with } \\
\text { all term children this decrease in risk } \\
\text { was not statistically significant. }\end{array}$ & $\begin{array}{l}\text {-the } \\
\text { healthy } \\
\text { vaccine } \\
\text { effect } \\
\text { - } \\
\text { emergency } \\
\text { room visits } \\
\text { and } \\
\text { hospital } \\
\text { admissions } \\
\text { within } 3 \\
\text { days } \\
\text { following } \\
\text { vaccination } \\
\text { could not } \\
\text { be related } \\
\text { to } \\
\text { vaccination }\end{array}$ \\
\hline $\begin{array}{l}\text { Clifford V } \\
\text { et al }(2011) \\
34\end{array}$ & $\begin{array}{l}\text { Observational } \\
\text { retrospective }\end{array}$ & 46 & $\begin{array}{l}-38 \text { born } \\
<37 \mathrm{w} \\
-8 \text { born } \\
\geq 37 \mathrm{w}\end{array}$ & Australia & $\begin{array}{l}\text { DTPa-IPV- } \\
\text { HBV- } \\
\mathrm{HiB}+\mathrm{PCV} 7 \\
\text { and } \\
\text { rotavirus } \\
\text { vaccine }\end{array}$ & $\begin{array}{l}\text {-To determine recurrence } \\
\text { rates for AEs following } 2 \\
\text { or } 4 \text { month immunisations } \\
\text { over } 48 \text { hours after } \\
\text { vaccination. } \\
\text {-To explore potential risk } \\
\text { factors for recurrence of } \\
\text { apnea }\end{array}$ & 48 hours & $\begin{array}{l}-35 / 38 \text { preterm infants had an apnoea } \\
\text { following their } 2 \text {-month vaccine, } \\
3 / 38 \text { had an apnea after their } 4- \\
\text { month vaccine } \\
-7 / 38(18 \%) \text { preterm infants had } \\
\text { recurrent apnoea } \\
\text {-Lower birth weight }(\mathrm{p}=0.04) \text { and } \\
\text { ongoing hospitalisation for } \\
\text { complications relating to prematurity } \\
(\mathrm{p}=0.01) \text { increased the odds of a } \\
\text { recurrent apnoea AEFI. } \\
\text { - No infant with recurrent apnoea at } \\
\text { 4-months suffered a third apnoea } \\
\text { AEFI at their 6-month } \\
\text { immunisations }\end{array}$ & $\begin{array}{l}\text {-small } \\
\text { sample size } \\
\text { - } \\
\text { overestima } \\
\text { tion of the } \\
\text { number of } \\
\text { infants } \\
\text { with a first } \\
\text { apnoea } \\
\text { AEFI } \\
\text { maybe } \\
\text { because of } \\
\text { the } \\
\text { retrospecti } \\
\text { ve nature } \\
\text { of the } \\
\text { study } \\
\text { without the } \\
\text { possibility } \\
\text { to confirm } \\
\text { the } \\
\text { apnoea } \\
\text { diagnosis }\end{array}$ \\
\hline $\begin{array}{l}\text { Esposito et } \\
\text { al. } \quad(2011) \\
48\end{array}$ & $\begin{array}{l}\text { Prospective, } \\
\text { randomized } \\
\text { open trial }\end{array}$ & 101 & $\begin{array}{l}-34 \text { born } \\
<32 \mathrm{w} \\
-35 \text { born } \\
32-36 \mathrm{w} \\
-32 \text { born } \\
\geq 37 \mathrm{w}\end{array}$ & Italy & $\begin{array}{l}\text { Influenza } \\
\text { A/H1N1 } \\
\text { MF59- } \\
\text { adjuvanted } \\
\text { vaccine }\end{array}$ & $\begin{array}{l}\text { To assess immunogenicity, } \\
\text { safety and tolerability of } \\
\text { influenza A/H1N1 MF59- } \\
\text { adjuvanted vaccine in } \\
\text { preterm and term children } \\
\text { aged } 6 \text { to } 23 \text { months }\end{array}$ & 14 days & $\begin{array}{l}\text {-The incidence of local AEs was } 2,9- \\
3,1 \% \text { in all children } \\
\text {-The only systemic AE consistently } \\
\text { recorded was fever, more frequently } \\
\text { after the first dose than after the } \\
\text { second dose in all the } \\
\text { groups }(\mathrm{P}<0.05) \\
\text {-None of the enrolled children } \\
\text { experienced any severe AE. }\end{array}$ & \\
\hline $\begin{array}{l}\text { Omeñaca et } \\
\text { al (2011) } 53\end{array}$ & $\begin{array}{l}\text { open, } \\
\text { controlled } \\
\text { prospective } \\
\text { multicenter } \\
\text { study }\end{array}$ & 313 & $\begin{array}{l}-56 \text { born } \\
<31 \mathrm{w} \\
-107 \\
\text { born } 31- \\
36 \mathrm{w} \\
-150 \text { full } \\
\text { term }\end{array}$ & Spain & $\begin{array}{l}\text { Hib-MenC- } \\
\text { TT }\end{array}$ & $\begin{array}{l}\text { To assess immunogenicity } \\
\text { and safety profile in } \\
\text { preterm infants compared } \\
\text { with full-term born } \\
\text { infants. } \\
\text { To record specific local } \\
\text { and general solicited } \\
\text { adverse events for } 4 \text { days } \\
\text { after each vaccination and }\end{array}$ & 31 days & $\begin{array}{l}\text {-solicited local symptoms tended to } \\
\text { be lower than those observed after } \\
\text { DTPa-HBV-IPV-PCV7 } \\
\text {-Grade } 3 \text { local symptoms were } \\
\text { reported by no more than } 7.6 \% \\
\text {-No evidence of increasing } \\
\text { reactogenicity with an increasing } \\
\text { number of doses in any group. } \\
\text {-Grade } 3 \text { general symptoms were }\end{array}$ & $\begin{array}{l}\text {-open } \\
\text { design } \\
\text {-no } \\
\text { randomizat } \\
\text { ion }\end{array}$ \\
\hline
\end{tabular}




\begin{tabular}{|c|c|c|c|c|c|c|c|c|c|}
\hline & & & & & & $\begin{array}{l}\text { to record unsolicited } \\
\text { adverse events for } 31 \text { days } \\
\text { after vaccination }\end{array}$ & & $\begin{array}{l}\text { reported by no more than } 9.3 \% \text { and } \\
2.8 \% \text { of patients after primary } \\
\text { vaccination and after the booster } \\
\text { dose respectively }\end{array}$ & \\
\hline $\begin{array}{l}\text { Omeñaca et } \\
\text { al(2011) } 54\end{array}$ & $\begin{array}{l}\text { Prospective } \\
\text { clinical trial }\end{array}$ & 286 & $\begin{array}{l}-50 \text { born } \\
27-30 \mathrm{w} \\
-87 \text { born } \\
31-36 \mathrm{w} \\
-149 \text { full } \\
\text { term }\end{array}$ & $\begin{array}{l}\text { Spain, } \\
\text { Greece }\end{array}$ & PHID-CV & $\begin{array}{l}\text { To evaluate } \\
\text { immunogenicity and } \\
\text { safety to PHiD-CV and } \\
\text { coadministered vaccine at } \\
2-4-6 \text { month of age, } \\
\text { followed by a booster dose } \\
\text { at } 16-18 \text { months of age. } \\
\text { To evaluate local and } \\
\text { general adverse events for } \\
4 \text { days after each vaccine } \\
\text { dose and unsolicited } \\
\text { adverse events for } 31 \text { days } \\
\text { after vaccine and serious } \\
\text { adverse events for } 6 \\
\text { months after booster } \\
\text { vaccination. }\end{array}$ & $\begin{array}{l}6 \\
\text { months }\end{array}$ & $\begin{array}{l}\text {-The most frequently reported } \\
\text { solicited general AE were irritability, } \\
\text { drowsiness, fever and loss of } \\
\text { appetite, but the incidence of high } \\
\text { grade of general AE was low (i.e. } \\
0,8-1,5 \% \text { incidence of fever }>39^{\circ} \mathrm{C} \\
\text { within } 4 \text { days after each of the } \\
\text { vaccine doses, } 7.1 \% \text { after the booster } \\
\text { dose) } \\
\text {-Incidence of grade } 3 \text { solicited local } \\
\text { AEs was low in both groups, but } \\
\text { higher after booster vaccination in } \\
\text { the term group. } \\
\text {-SAEs were reported but no one } \\
\text { were considered as causally related } \\
\text { to vaccination } \\
\text { - One episode of apnea was reported } \\
\text { in a preterm infant after the first } \\
\text { primary dose but was not considered } \\
\text { to be related to study vaccination and } \\
\text { resolved without sequelae. }\end{array}$ & \\
\hline $\begin{array}{l}\text { Furck et al } \\
(2010) 57\end{array}$ & $\begin{array}{l}\text { prospective } \\
\text { observational } \\
\text { trial }\end{array}$ & 473 & $<37 \mathrm{w}$ & Germany & $\begin{array}{l}\text { DTPa, Hib, } \\
\text { HBV, IPV, } \\
\text { PCV7 }\end{array}$ & $\begin{array}{l}\text { To assess AEs for up to } \\
48 \mathrm{~h} \text { following vaccination }\end{array}$ & 48 hours & $\begin{array}{l}\text {-The frequency of side effects was } \\
10.8 \% \text { and } 2.8 \% \text { for } \\
\text { apnea/bradycardia and local } \\
\text { reaction/fever respectively } \\
\text {-The chance of suffering from apnea } \\
\text { decreased with increasing gestational } \\
\text { week at birth } \\
\text {-Fever was significantly more } \\
\text { frequent in infants with cerebral } \\
\text { hemorrhage grade 3-4 or with } \\
\text { periventricular leukomalacia (OR } 8,7 \\
\text { and } 8,2 \text { respectively) }\end{array}$ & $\begin{array}{l}\text {-The } 3 \\
\text { groups did } \\
\text { not have } \\
\text { the same } \\
\text { number of } \\
\text { infants } \\
\text {-the } \\
\text { gestational } \\
\text { age as the } \\
\text { time of } \\
\text { vaccination } \\
\text { decreased } \\
\text { over the } \\
\text { years }\end{array}$ \\
\hline $\begin{array}{l}\text { Hacking et } \\
\text { al. } \quad(2010) \\
59\end{array}$ & $\begin{array}{l}\text { Retrospective } \\
\text { historical } \\
\text { cohort study }\end{array}$ & 411 & $27 \mathrm{w}$ & Australia & $\begin{array}{l}\text { DTPa, Hib, } \\
\text { HBV, } \\
\text { OPV/IPV, } \\
\text { PCV7 }\end{array}$ & $\begin{array}{l}\text { To evaluate initiation of } \\
\text { respiratory support } \\
\text { (CPAP) or intermittent } \\
\text { positive pressure } \\
\text { ventilation (IPPV) within } \\
7 \text { days of the 2-month } \\
\text { scheduled vaccination }\end{array}$ & 7 days & $\begin{array}{l}-22 \text { preterm infants experienced } \\
\text { some respiratory deterioration in the } \\
\text { first } 3 \text { day after vaccination } \\
\text { attributed solely to the immunization } \\
\text {-infants requiring respiratory support } \\
\text { following vaccination had a higher } \\
\text { incidence of previous septicaemia ( } \mathrm{p} \\
=0.02 \text { ) and had a greater mean total } \\
\text { accumulated time on CPAP prior to } \\
\text { receiving immunizations ( } \mathrm{p}=0.03 \text { ) }\end{array}$ & $\begin{array}{l}\text { - } \\
\text { retrospecti } \\
\text { ve nature } \\
\text { of the } \\
\text { study } \\
\text { cannot } \\
\text { suggest } \\
\text { that } \\
\text { immunizati } \\
\text { on was a } \\
\text { causative } \\
\text { factor }\end{array}$ \\
\hline $\begin{array}{l}\text { Klein et al } \\
(2010) 50\end{array}$ & $\begin{array}{l}\text { open-label } \\
\text { prospective } \\
\text { study, self- } \\
\text { controlled } \\
\text { case series } \\
\text { approach }\end{array}$ & 83 & $\begin{array}{l}-33 \text { born } \\
<37 \mathrm{w} \\
-50 \\
\text { born } \geq 37 \\
\mathrm{w}\end{array}$ & & $\begin{array}{l}\text { DTPa, Hib, } \\
\text { HBV, IPV, } \\
\text { PCV }\end{array}$ & $\begin{array}{l}\text { to describe potential } \\
\text { vaccine-related AEs } \\
\text { during the } 30 \text { days after } \\
\text { each of } 3 \text { doses comparing } \\
\text { the frequency of these } \\
\text { events in preterm and term } \\
\text { infants }\end{array}$ & 30 days & $\begin{array}{l}\text {-No AEs like fever, seizure, or } \\
\text { swelling were reported for either } \\
\text { preterm or term infants } \\
\text {-Self-controlled case series analyses } \\
\text { showed no increase in AEs among } \\
\text { preterm and term infants after any } \\
\text { vaccine dose }\end{array}$ & $\begin{array}{l}\text { Small } \\
\text { sample size }\end{array}$ \\
\hline $\begin{array}{l}\text { Carbone et } \\
\text { al. (2008) } \\
61\end{array}$ & $\begin{array}{l}\text { Randomized, } \\
\text { controlled, } \\
\text { blinded } \\
\text { multicenter } \\
\text { study }\end{array}$ & 197 & $<37 w$ & USA & DTPa & $\begin{array}{l}\text { To evaluate increase in } \\
\text { cardiorespiratory events } \\
\text { after DTPa in preterm } \\
\text { infants }\end{array}$ & 48 hours & $\begin{array}{l}\text { Absence of increase in } \\
\text { cardiorespiratory events in } \mathrm{DTaP} \\
\text { group versus the control group }\end{array}$ & $\begin{array}{l}\text { no long- } \\
\text { term } \\
\text { observatio } \\
\mathrm{n} \text { of the } \\
\text { untreated } \\
\text { control } \\
\text { group. }\end{array}$ \\
\hline $\begin{array}{l}\text { Flatz- } \\
\text { Jequier et al } \\
(2008) 35\end{array}$ & $\begin{array}{l}\text { Retrospective } \\
\text { study }\end{array}$ & 64 & $<32 \mathrm{w}$ & $\begin{array}{l}\text { Switzerlan } \\
\text { d }\end{array}$ & $\begin{array}{l}\text { DTPa- } \\
\text { IPV/HIB/- } \\
\text { PCV/anti } \\
\text { VRS }\end{array}$ & $\begin{array}{l}\text { To evaluate occurrence of } \\
\text { cardiorespiratory events } \\
\text { after first } \\
\text { DTPw or DTPa } \\
\text { immunization in VLBW } \\
\text { during the first } 48 \text { hours } \\
\text { after second dose of } \\
\text { vaccine }\end{array}$ & 48 hours & $\begin{array}{l}\text {-33/64 showed significant } \\
\text { cardiorespiratory event after the } 2 \\
\text { months vaccine. } \\
-6 / 33 \text { require medical intervention } \\
\text { (i.e. oxygen supplementation through } \\
\text { nasal cannula in } 4 \text { patients, tactile } \\
\text { stimulation in } 1 \text { patients, mask } \\
\text { ventilation in } 1 \text { patients) after the } 4 \\
\text { months vaccine } \\
\text {-None showed significant } \\
\text { cardiorespiratory event after the third } \\
\text { vaccine } \\
\text {-A previous AE to vaccine was a risk } \\
\text { factors for recurrence of } \\
\text { cardiorespiratory events. }\end{array}$ & $\begin{array}{l}\text { retrospecti } \\
\text { ve study }\end{array}$ \\
\hline $\begin{array}{l}\text { Klein et al. } \\
(2008) 60\end{array}$ & $\begin{array}{l}\text { Retrospective } \\
\text { study }\end{array}$ & 497 & $\begin{array}{l}456 \text { born } \\
\leq 30 \text { w }\end{array}$ & USA & $\begin{array}{l}\text { DTPa-IPV- } \\
\text { HBV-Hib- }\end{array}$ & $\begin{array}{lr}\text { To assess } & \text { factors } \\
\text { associated } & \text { with }\end{array}$ & 48 hours & $\begin{array}{l}\text { - } 95 \% \text { episodes of postimmunization } \\
\text { apnea ( } 62 \text { of } 65 \text { episodes) occurred }\end{array}$ & \\
\hline
\end{tabular}




\begin{tabular}{|c|c|c|c|c|c|c|c|c|}
\hline & & & & & $\begin{array}{l}\text { and } 4 \text { months of } \\
\text { age) } \\
\text {-group } \\
\text { extended } \\
\text { schedule } \\
\text { (vaccine at 2, 4, } \\
\text { and } 6 \text { months of } \\
\text { age) }\end{array}$ & & $\begin{array}{l}\text { concentrations. } \\
\text {-Later gestation was associated } \\
\text { with an increase in post-primary } \\
\text { vaccination IgG concentrations } \\
\text { for some serotypes, while receipt } \\
\text { of antenatal steroids was } \\
\text { associated with decreased odds of } \\
\text { seroprotection at } 2 \text { months and } \\
\text { after primary immunization for } \\
\text { some serotypes. }\end{array}$ & \\
\hline $\begin{array}{l}\text { Saroha et al. } \\
(2015) 42\end{array}$ & $\begin{array}{l}\text { Prospective } \\
\text { randomized } \\
\text { comparative } \\
\text { trial }\end{array}$ & $\begin{array}{l}117 \\
-69 \text { received BCG at } \\
\text { birth (group 1) } \\
-48 \text { received BCG at } \\
34 \mathrm{w} \text { (group 2) }\end{array}$ & $31-33 w$ & India & BCG & $\begin{array}{lr}\text { To } & \text { evaluate } \\
\text { immunogenicity of } \\
\text { early vs delayed BCG } \\
\text { vaccination } \\
\text { moderately } & \text { preterm } \\
(31-33 & \text { weeks }) \\
\text { infants. } & \end{array}$ & $\begin{array}{l}\text {-the rise of IFN-g levels measured } \\
6 \text { months after BCG in } 2 \text { groups } \\
\text { was comparable }(\mathrm{p}>0.05) \\
\text {-In group } 1,39.1 \% \text { infants had } \\
\text { positive Mantoux reaction }(5-9 \\
\mathrm{mm}) 6 \text { months after BCG whereas } \\
37.5 \% \text { infants in group } 2 \text { had } \\
\text { positive Mantoux test }(\mathrm{p}=0.473) \\
\text {-Six infants }(5.12 \%) \text { failed to } \\
\text { develop BCG scar } \\
\text { - the overall immunogenicity of } \\
\text { BCG was } 98.3 \%\end{array}$ & \\
\hline $\begin{array}{l}\text { van den Berg } \\
(2015) 66\end{array}$ & $\begin{array}{l}\text { Prospective } \\
\text { randomized } \\
\text { trial }\end{array}$ & $\begin{array}{l}113 \text { divided into } \\
2 \text { groups: } \\
-1 \text { group received } \\
\text { enteral } \\
\text { oligosaccharides } \\
\text { mixture during days } \\
3-30 \text { of life } \\
-1 \text { group received } \\
\text { placebo }\end{array}$ & $<32 \mathrm{w}$ & $\begin{array}{l}\text { The } \\
\text { Netherlands }\end{array}$ & $\begin{array}{l}\text { PCV } 7 \text { (4 doses } \\
\text { at } 2,3,4 \text { and } 11 \\
\text { months of age) }\end{array}$ & $\begin{array}{l}\text { to investigate the } \\
\text { specific antibody } \\
\text { levels against the } 7 \\
\text { pneumococcal } \\
\text { vaccine serotypes } 4- \\
6 \text { weeks after the } \\
\text { third pneumococcal } \\
\text { immunization and } 4- \\
8 \text { weeks after the } \\
\text { booster dose }\end{array}$ & $\begin{array}{l}\text { - IgG antibody levels in preterm } \\
\text { infants supplemented with } \\
\text { oligosaccharides were similar to } \\
\text { those of term infants at } 5 \text { months } \\
\text { of age, while IgG antibody levels } \\
\text { in preterm infants supplemented } \\
\text { with placebo were higher for } 5 \text { of } \\
\text { the } 7 \text { vaccine serotypes (serotypes } \\
4,6 \mathrm{~B}, 9 \mathrm{~V}, 19 \mathrm{~F}, 23 \mathrm{~F} ; \mathrm{P}<0.05 \text { ) } \\
\text { than those in term infants. } \\
\text {-At } 12 \text { months of age, there was a } \\
\text { significant booster response in } \\
\text { both preterm groups and the } \\
\text { GMCs of pneumococcal antibody } \\
\text { levels after the booster dose for all } \\
\text { serotypes were not different in the } \\
\text { two groups } \\
\text {-preterm infants with higher } \\
\text { gestational age showed higher } \\
\text { pneumococcal antibody } \\
\text { concentrations of certain } \\
\text { serotypes at } 5 \text { and } 12 \text { months }\end{array}$ & \\
\hline $\begin{array}{l}\text { Szynczewska } \\
\text { et al (2014) } \\
65\end{array}$ & $\begin{array}{l}\text { Observational } \\
\text { prospective }\end{array}$ & $\begin{array}{l}60 \\
\text {-Group I } 23 \text { born } \\
\text { with birth weight } \\
<1000 \mathrm{~g} ; \\
\text {-Group II } \\
37 \text { born with birth } \\
\text { weight } \geq 1000 \mathrm{~g}\end{array}$ & 24-34 weeks & & PCV7 & $\begin{array}{l}\text { To assess } \\
\text { concentration } \\
\text { of specific } \\
\text { immunoglobulin G } \\
\text { against all } \\
\text { seven serotypes of } \\
\text { PCV7 4 weeks after } \\
\text { the r primary } \\
\text { vaccination; prior and } \\
4 \text { weeks later the } \\
\text { booster a dose } \\
\text { administration. }\end{array}$ & $\begin{array}{l}\text { - After primary immunization, an } \\
\text { increase in the average } \\
\text { concentration of antibodies for all } \\
\text { serotypes was observed in most } \\
\text { children, with no significant } \\
\text { differences between groups. } \\
\text {-Serotypes 6B and } 23 \mathrm{~F} \text { proved to } \\
\text { be the least immunogenic } \\
\text { following the primary vaccination } \\
\text {-Prior to administration of the } \\
\text { booster dose at age } 16 \text { months a } \\
\text { significant decrease in antibody } \\
\text { titer was observed in all } \\
\text { children } \\
\text { - The last vaccination resulted in } \\
\text { another significant increase in the } \\
\text { concentration of antibodies } \\
\text { in both groups. }\end{array}$ & \\
\hline $\begin{array}{l}\text { Ichikawa et } \\
\text { al (2013) } 41\end{array}$ & $\begin{array}{l}\text { Observational } \\
\text { prospective } \\
\text { Clinical trial }\end{array}$ & $\begin{array}{l}161 \quad(17 \quad \text { received } \\
\text { early vaccination at } 6 \\
\text { months) }\end{array}$ & $<34 \mathrm{w}$ & Japan & Measles & $\begin{array}{l}\text { To evaluate antibody } \\
\text { titers before and after } \\
\text { early vaccination at } 6 \\
\text { months for measles }\end{array}$ & $\begin{array}{l}\text { - The antibody titers at birth was } \\
\text { significantly lower in preterm } \\
\text { infants born }<28 \text { weeks }(\mathrm{P}<0.05) \\
\text { and with a weight }<1000 \mathrm{~g}(\mathrm{P}< \\
0.01) \text {. } \\
\text {-At } 3-6 \text { months of age, none of } \\
\text { the } 108 \text { infants tested had } \\
\text { protective antibody titers. } \\
\text {-Preterm infants who received } \\
\text { early vaccination at } 6 \text { months kept } \\
\text { antibodiy titers positive in all } \\
\text { cases } 1 \text { month after vaccination. } \\
\text {-Titers did not decay during the } 12 \\
\text { months after vaccination }\end{array}$ & $\begin{array}{ll}\text { Small sample } \\
\text { size }\end{array}$ \\
\hline $\begin{array}{l}\text { Vermeulen et } \\
\text { al. (2013) } 70\end{array}$ & $\begin{array}{l}\text { Observational } \\
\text { prospective } \\
\text { cohort study }\end{array}$ & $\begin{array}{l}68 \\
-22 \text { vaccinated with } \\
\text { whole cell pertussis } \\
\text { vaccine }(\mathrm{Pw}) \\
-24 \text { vaccinated with } \\
\text { two components }\end{array}$ & $<31 \mathrm{w}$ & Belgium & $\begin{array}{l}3 \text { type of } \\
\text { vaccines: } \\
\mathrm{Pw}, \\
\mathrm{Pa} \text { bicomponent, } \\
\mathrm{Pa} \\
\text { multicomponent }\end{array}$ & $\begin{array}{l}\text { To assess at one year } \\
\text { of age the specific } \\
\text { cellular } \\
\text { immune responses in } \\
\text { the preterm infants } \\
\text { (through cytokine }\end{array}$ & $\begin{array}{l}\text {-more than half of premature } \\
\text { infants vaccinated with the Pw } \\
\text { vaccine or with the } 2 \text { component } \\
\text { Pa vaccine developed at } 3 \text { and/or } \\
\text { at } 6 \text { months of age an IFN-r } \\
\text { response to FHA and/or PT }\end{array}$ & $\begin{array}{l}\text { Small sample } \\
\text { size }\end{array}$ \\
\hline
\end{tabular}




\begin{tabular}{|c|c|c|c|c|c|c|c|c|}
\hline & & $\begin{array}{l}\text { acellular vaccine }(\mathrm{Pa}) \\
-22 \text { vaccinated with } \\
\text { three component } \\
\text { Pa vaccine. }\end{array}$ & & & & $\begin{array}{l}\text { secretion after } \\
\text { antigenic stimulation) }\end{array}$ & $\begin{array}{l}\text { - no effect of the booster dose was } \\
\text { observed on the FHA or PT- } \\
\text { induced IFN- } \gamma \text { secretion in the } 3 \\
\text { groups } \\
\text { - Pa vaccine induced more } \\
\text { secretion of Th2 cytokines in } \\
\text { response to FHA and to PT, } \\
\text { compared to infants primed with a } \\
\text { Pw vaccine }\end{array}$ & \\
\hline $\begin{array}{l}\text { Omenaca et } \\
\text { al. (2012) } 46\end{array}$ & $\begin{array}{l}\text { phase IIIb, } \\
\text { randomized } \\
\text { double blind, } \\
\text { multicenter, } \\
\text { placebo- } \\
\text { controlled } \\
\text { trial }\end{array}$ & 228 & $\geq 27$ and $<37 w$ & $\begin{array}{l}\text { France, } \\
\text { Portugal, } \\
\text { Poland, } \\
\text { Spain }\end{array}$ & Rotavirus & $\begin{array}{l}\text { To assess } \\
\text { immunogenicity of a } \\
\text { human rotavirus } \\
\text { vaccine dosing IgA } \\
\text { specific antibody } \\
\text { concentrations } 30-83 \\
\text { days post-dose 2 }\end{array}$ & $\begin{array}{l}\text { seroconversion rate at } 30-83 \text { days } \\
\text { post dose } 2 \text { of vaccine/placebo } \\
\text { was } 85.7 \% \text { (95\% CI: } 79.0- \\
90.9 \%) \text { in vaccine group and } \\
16.0 \%(95 \% \text { CI: } 8.8-25.9 \%) \text { in } \\
\text { the placebo group }\end{array}$ & \\
\hline $\begin{array}{l}\text { Tsuda et al. } \\
\text { (2012) } 47\end{array}$ & $\begin{array}{l}\text { Observational } \\
\text { prospective } \\
\text { cohort }\end{array}$ & 54 & $<37 \mathrm{w}$ & Japan & Hib & $\begin{array}{l}\text { to evaluate vaccine } \\
\text { immunogenicity in } \\
\text { preterm infants by } \\
\text { measuring antibody } \\
\text { PRP titers as GMCs } \\
\text { before and } 1 \text { month } \\
\text { after the third dose }\end{array}$ & $\begin{array}{l}\text { - after three doses of vaccine, } \\
\text { GMCs increased from } 0.06 \text {. to } \\
2.89 \mathrm{mg} / \mathrm{mL}(\mathrm{P}<0.001) \text {. } \\
\text {-The seroconversion rate was } \\
85.2 \% \\
\text { - the seroconversion rate after } \\
\text { vaccination of infants with a } \\
\text { history of antenatal exposure to } \\
\text { steroids was higher than those } \\
\text { without antenatal exposure ( } \mathrm{P}= \\
0.046) \text {. } \\
\text { - the seroconversion rate of group } \\
\text { vaccinated at the age of } 2 \text { months } \\
\text { was close to being significantly } \\
\text { worse than the group vaccinated } \\
\text { at the age of }>3 \text { months (P = } \\
0.060)\end{array}$ & $\begin{array}{l}\text { Small sample } \\
\text { size }\end{array}$ \\
\hline $\begin{array}{l}\text { Esposito et } \\
\text { al. }(2011) 48\end{array}$ & $\begin{array}{l}\text { Prospective, } \\
\text { randomized } \\
\text { study }\end{array}$ & 101 & $\begin{array}{l}-34 \text { born }<32 \mathrm{w} \\
-35 \text { born } 32-36 \\
\mathrm{w} \\
-32 \text { born } \geq 37 \mathrm{w}\end{array}$ & Italy & $\begin{array}{l}\text { Influenza } \\
\text { A/H1N1 MF59- } \\
\text { adjuvanted } \\
\text { vaccine }\end{array}$ & $\begin{array}{l}\text { To assess } \\
\text { immunogenicity of } \\
\text { influenza A/H1N1 } \\
\text { MF59-adjuvanted } \\
\text { vaccine in preterm } \\
\text { and term children } \\
\text { aged } 6 \text { to } 23 \text { months } \\
\text { evaluating antibody } \\
\text { titers collected } \\
\text { immediately before } \\
\text { administration of } \\
\text { dose } 1 \text {, dose } 2 \text { and } 4 \\
\text { weeks later the dose } \\
2 .\end{array}$ & $\begin{array}{l}\text {-the first dose was able to } \\
\text { determine seroprotection in all of } \\
\text { the preterm born between } 32 \text { and } \\
36 \text { weeks of gestation } \\
\text {-After the administration of the } \\
\text { vaccine, there was a significant } \\
\text { increase in the GMCs of all the } \\
\text { children }(\mathrm{P}<0.05) \\
\text {-The preterm subjects with a } \\
\text { gestational age }<32 \text { weeks aged } 6 \\
\text { to } 11 \text { months had significantly } \\
\text { lower absolute GMCs than the } \\
\text { subjects in any of the other groups } \\
(\mathrm{P}<0.05)\end{array}$ & \\
\hline $\begin{array}{l}\text { Omeñaca et } \\
\text { al. (2011) } 54\end{array}$ & $\begin{array}{l}\text { Prospective } \\
\text { clinical trail }\end{array}$ & 286 & $\begin{array}{l}\text {-preterm } \\
\text { group } \\
\text { (between 27and } \\
30 \mathrm{w} \text { ); } \\
\text {-preterm group } \\
\text { II } \\
\text { (between } 31 \text { and } \\
36 \mathrm{w} \\
\text {-term group }\end{array}$ & $\begin{array}{l}\text { Spain, } \\
\text { Greece }\end{array}$ & PHiD-CV & $\begin{array}{l}\text { To evaluate } \\
\text { immunogenicity to } \\
\text { PHiD-CV at 2, 4, and } \\
6 \text { months of age } \\
\text { evaluating antibody } \\
\text { titers like OPA o } \\
\text { GMC 1 month after } \\
\text { primary vaccination, } \\
\text { and 1 month after } \\
\text { booster vaccination. }\end{array}$ & $\begin{array}{l}\text {-at least } 92.7 \% \text { of } \\
\text { infants in each group had antibody } \\
\text { GMCs } \\
\text { concentrations }>0.2 \mu \mathrm{g} / \mathrm{mL} \text { and at } \\
\text { least } 93.2 \% \text { of subjects had } \\
\text { OPA titers }>8 \quad 1 \text { month after } \\
\text { primary immunization. } \\
\text {-preterm infants showed lower } \\
\text { antibody titers for certain } \\
\text { serotypes } \\
\text {-at least } 97.6 \% \text { of subjects in each } \\
\text { group developed antibody } \\
\text { concentrations >0.2 } \mu \mathrm{g} / \mathrm{mL} 1 \\
\text { month after booster dose. } \\
\text {-One month after both primary } \\
\text { and booster vaccination, all } \\
\text { subjects were } \\
\text { seroprotected/seropositive for } \\
\text { antibodies against the antigens of } \\
\text { the coadministered vaccines, } \\
\text { except } 1 \text { subject in preterm group } \\
\text { I after primary vaccination who } \\
\text { was not seroprotected } \\
\text { against polio type } 3 \text {. }\end{array}$ & \\
\hline $\begin{array}{l}\text { Omenaca et } \\
\text { al, (2011) } 53\end{array}$ & $\begin{array}{l}\text { phase IIIb } \\
\text { open, } \\
\text { controlled } \\
\text { multicenter } \\
\text { prospective } \\
\text { study }\end{array}$ & 309 & $\begin{array}{l}-56 \text { preterm I: } \\
\leq 31 \mathrm{w} \\
-107 \text { preterm II } \\
\text { between } 32 \text { and } \\
36 \mathrm{w} \\
-150 \text { full term } \\
\text { infants }\end{array}$ & Spain & $\begin{array}{l}\text { Hib-MenC-TT } \\
\text { and PCV7 at } 2, \\
4,6 \text { months and } \\
\text { at } 16 \text { to } 18 \\
\text { months of age }\end{array}$ & 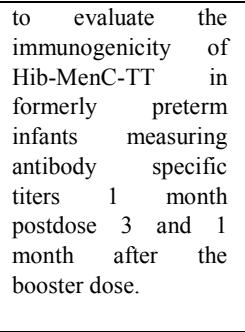 & $\begin{array}{l}\text {-the percentage of subjects with } \\
\text { seroprotective anti-PRP antibody } \\
\text { concentrations was } \geq 99 \% \text { in all } \\
\text { groups. } \\
\text {-Booster vaccination induced } \\
\text { marked increases in anti-PRP } \\
\text { antibody GMCs, after a reduction } \\
\text { of the percentage of subjects with } \\
\text { seroprotective anti PRP before the } \\
\text { booster } \\
\text {-At least } 99.0 \% \text { and } 97,3 \% \text { of }\end{array}$ & Open design \\
\hline
\end{tabular}




\begin{tabular}{|c|c|c|c|c|c|c|c|}
\hline & & & & & & & $\begin{array}{l}\text { subjects in each age stratum had } \\
\text { rSBAMenC titers } \geq 1: 8 \\
\text { postprimary vaccination and post } \\
\text { booster dose respectively. } \\
\text { - At least } 97.5 \% \text { of infants in } \\
\text { each age stratum had anti-HBs } \\
\text { concentrations }>10 \mathrm{mIU} / \mathrm{mL} \text { at } 1 \\
\text { month postdose } 3 \\
\text {-The postdose } 3 \text { anti-HBV GMCs } \\
\text { was significantly lower in the } \\
\text { preterm I group than in the } \\
\text { preterm II and full-term groups }\end{array}$ \\
\hline $\begin{array}{l}\text { Baxter et al } \\
(2010) 72\end{array}$ & $\begin{array}{l}\text { Prospective } \\
\text { pragmatic } \\
\text { case series }\end{array}$ & 131 & $<32 \mathrm{w}$ & UK & $\begin{array}{l}\text { DT-Hib-MenC- } \\
\text { PCV }\end{array}$ & $\begin{array}{l}\text { to show antibody } \\
\text { response in premature } \\
\text { infants to DT-Hib- } \\
\text { MenC-PCV, in a } \\
\text { routine } \\
\text { situation }\end{array}$ & $\begin{array}{l}-98.3 \% \text { and } 100 \% \text { of premature } \\
\text { infants respectively developed a } \\
\text { minimum protective antibody } \\
\text { response; } \\
-86.6 \% \text { premature infants were } \\
\text { protected against Men C. } \\
\text { However, only } 67.8 \% \text { preterm } \\
\text { infants achieved anti-polyribosyl } \\
\text { ribitolphosphate (PRP) antibodies } \\
>0.15 \mu \text { against Hib } \\
\text {-Responses to the different } \\
\text { pneumococcal serogroups ranged } \\
\text { from } 67.5 \% \text { to } 92.5 \% \text {. } \\
\text { - In comparison to term infants, } \\
\text { preterm infants were less likely to } \\
\text { achieve protective levels against } \\
\text { MenC and Hib inferior to } \\
\text {-Protection was in published } \\
\text { expected based on ped } \\
\text { premature infant clinical trial data } \\
\text { for Hib, some pneumococcal } \\
\text { serotypes and Men C. }\end{array}$ \\
\hline $\begin{array}{lll}\text { Klein et } & \text { al. } \\
(2010) & 50 & \end{array}$ & $\begin{array}{l}\text { Observational } \\
\text { open-label } \\
\text { prospective } \\
\text { study }\end{array}$ & $\begin{array}{l}88 \\
-33 \leq 33 w \\
-50>37 w\end{array}$ & $\leq 33-37 \mathrm{w}$ & USA & & $\begin{array}{l}\text { To compare the } \\
\text { humoral and cellular } \\
\text { immune responses of } \\
\text { preterm infants to } \\
\text { those of term infants } \\
\text { after the primary } \\
\text { series of IPV given as } \\
\text { part of a combination } \\
\text { vaccine }\end{array}$ & $\begin{array}{l}\text {-preterm and term infants } \\
\text { developed comparable mean } \\
\text { frequencies of poliovirus-specific } \\
\text { memory } \mathrm{T} \text { cell responses } \\
\text { - About mononuclear cells } \\
\text { (PBMCs) proliferation preterm } \\
\text { infants were significantly less } \\
\text { likely to have a positive } \\
\text { stimulation index (SI) than term } \\
\text { infants (P=0.03) } \\
\text { - All infants with serum available } \\
\text { for testing had a seroprotective } \\
\text { antibody response to all } 3 \\
\text { poliovirus serotypes } \\
\text {-The GMCs to poliovirus serotype } \\
1 \text { was significantly lower in both } \\
\text { the group of all preterm infants }\end{array}$ \\
\hline $\begin{array}{l}\text { Moss et al. } \\
(2010)\end{array}$ & $\begin{array}{l}\text { Observational } \\
\text { prospective }\end{array}$ & 184 & $\begin{array}{l}-132 \text { preterm } \\
\text { infants } \\
-52 \text { full term } \\
\text { infants }\end{array}$ & UK & $\begin{array}{l}\text { PCV7 } \\
\text { administered } \\
\text { with Neisseria } \\
\text { meningitidis } \\
\text { group C (MCC), } \\
\text { diphtheria, } \\
\text { tetanus, } \\
\text { pertussis, polio, } \\
\text { and Hib } \\
\text { vaccines }\end{array}$ & $\begin{array}{l}\text { To assess } \\
\text { pneumococcal } \\
\text { serotype-specific IgG } \\
\text { antibody } \\
\text { concentrations for all } \\
\text { PCV7 4 weeks } \\
\text { following the third } \\
\text { immunization, and } \\
\text { either at } 12 \text { months of } \\
\text { age or 4 weeks after a } \\
\text { booster dose of PCV7 }\end{array}$ & $\begin{array}{l}\text { - only } 36 \% \text { term infants and } 34 \% \\
\text { preterm infants achieved } \\
\text { putatively protective levels } \\
\text { against all } 7 \text { vaccine serotypes, } \\
\text { - At } 12 \text { months of age, only } 22 \% \\
\text { term infants and } 11 \% \text { preterm } \\
\text { infants had putatively protective } \\
\text { levels against all vaccine } \\
\text { serotypes } \\
\text { - There was a significant increase } \\
\text { in GMCs for both term and } \\
\text { preterm infants for all serotypes, } \\
\text { including the } 2 \text { control serotypes } \\
\text { from post-primary immunizations } \\
\text { to post-fourth dose }(\mathrm{P}<0.01) \\
\text { - Preterm birth adversely affected } \\
\text { the GMCs to serotypes } \\
4,6 \mathrm{~B}, 14,19 \mathrm{~F} \text {, and } 23 \mathrm{~F}(\mathrm{P}<0.01) \text {. }\end{array}$ \\
\hline $\begin{array}{l}\text { Omeñaca et } \\
\text { al. }(2010) 73\end{array}$ & $\begin{array}{l}\text { Open label } \\
\text { trial }\end{array}$ & $\begin{array}{l}182 \\
-93 \text { preterm infants } \\
-89 \text { full term infants }\end{array}$ & $\begin{array}{l}-93 \text { preterm } \\
\text { infants } \\
-89 \text { full term } \\
\text { infants }\end{array}$ & Spain & $\begin{array}{l}\text { DTPa, IPV, } \\
\text { HBV, Hib }\end{array}$ & $\begin{array}{l}\text { To assess Hepatitis B } \\
\text { response of } \\
\text { premature infants } \\
\text { after primary and } \\
\text { booster immunisation } \\
\text { with hexavalent } \\
\text { vaccine }\end{array}$ & $\begin{array}{l}\text {-A total } 93.4 \% \text { preterm and } 95.2 \% \\
\text { full-term infants responded to } \\
\text { primary vaccination } \\
\text {-Six preterm infants }(6.59 \%) \text { did } \\
\text { not respond to primary } \\
\text { immunization and failed to } \\
\text { respond to the booster dose } \\
\text {-No responders had a gestational } \\
\text { age of at least } 31 \text { weeks and, } \\
\text { except for two, were severe IUGR }\end{array}$ \\
\hline $\begin{array}{l}\text { Faridi et al. } \\
(2009) 63\end{array}$ & $\begin{array}{l}\text { Observational } \\
\text { prospective }\end{array}$ & 143 & $31-41 \mathrm{w}$ & India & BCG & $\begin{array}{l}\text { To evaluate } \\
\text { immunogenicity of }\end{array}$ & $\begin{array}{l}-95.8 \% \text { had either a reactive } \\
\text { Mantoux test or positive LMIT } 6\end{array}$ \\
\hline
\end{tabular}




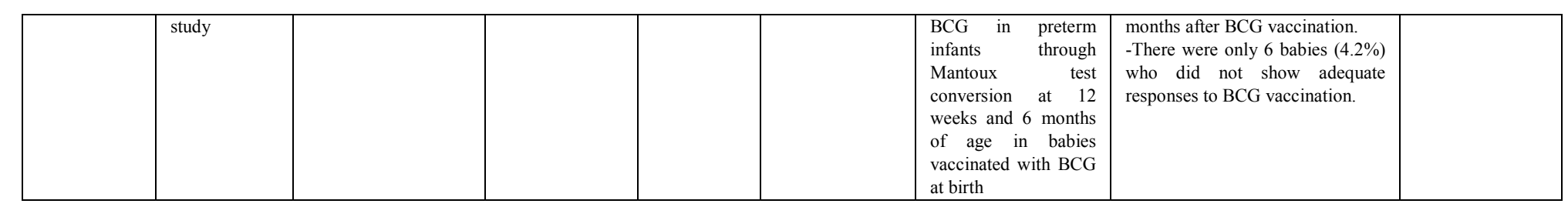

Table 4. Studies regarding vaccine immunogenicity in preterm infants [Notes:

$\mathrm{DTaP}=$ diphtheria, tetanus, acellular pertussis vaccine; $\mathrm{IPV}=$ inactivated polio vaccine; $\mathrm{OPV}=$ oral polio vaccine; $\mathrm{HBV}=$ hepatitis $\mathrm{B}$ vaccine; $\mathrm{PCV} 7$ heptavalent antipneumococcal vaccine; $\mathrm{PCV} 13=$ tridecavalent antipneumococcal vaccine; Hib= type B Haemophilus influenzae vaccine; Hib-MenC$\mathrm{TT}=$ Haemophilus influenza type B-Neisseria meningitidis serogroup $\mathrm{C}$ vaccine; $\mathrm{BCG}=\mathrm{Bacille}$ Calmette-Guérin vaccine; PHID-CV =PCV10-non typeable $\mathrm{H}$. influenzae protein D conjugate vaccine; SNAP-II: Score for Neonatal Acute Physiology II (SNAP-II), MMR=measles, mumps, and rubella vaccine; $\mathrm{GMCs}=$ geometric mean concentrations; $\mathrm{PRP}=$ anti-polyribosylribitolphosphate; $\mathrm{IPD}=$ invasive pneumococcal disease; LMIT=leukocyte migration inhibition test $]$.

\begin{tabular}{|c|c|c|c|c|c|c|c|c|}
\hline $\begin{array}{l}\text { Study } \\
\text { (year) }\end{array}$ & Design & No of pts & $\begin{array}{l}\text { Gestational } \\
\text { Age }\end{array}$ & Location & Vaccination & Objectives & Results & Bias \\
\hline $\begin{array}{l}\text { Roué et al. } \\
\text { (2014) } 45\end{array}$ & $\begin{array}{l}\text { Observational } \\
\text { prospective } \\
\text { population- } \\
\text { based } \\
\text { study }\end{array}$ & 201 & $<37 \mathrm{w}$ & France & $\begin{array}{l}\text { Rotavirus } \\
\text { vaccine }\end{array}$ & $\begin{array}{l}\text { To evaluate the } \\
\text { impact of the } \\
\text { pentavalent rotavirus } \\
\text { vaccine on the } \\
\text { number } \\
\text { hospitalizations for } \\
\text { rotavirus diarrhoea } \\
\text { in preterm infants } \\
\text { enrolled in the } \\
\text { IVANHOE study. }\end{array}$ & $\begin{array}{l}\text { - After introduction } \\
\text { of the vaccination program, a } 2.6- \\
\text { fold }(95 \% \mathrm{CI} \text {, } \\
1.3 \text { to } 5.2) \text { and an } 11 \text {-fold }(95 \% \\
\mathrm{CI}, 3.5 \text { to } 34.8) \text { decrease in the } \\
\text { number of hospitalizations for } \\
\text { rotavirus was detected in two } \\
\text { epidemic seasons in prematurely } \\
\text { born infants younger than } 3 \text { years } \\
\text { of age }\end{array}$ & \\
\hline $\begin{array}{l}\text { Shen et al. } \\
\text { (2013) } 69\end{array}$ & $\begin{array}{l}\text { Observational } \\
\text { retrospective }\end{array}$ & $\begin{array}{l}683,354 \quad(52903 \\
\text { preterm infants })\end{array}$ & $\begin{array}{l}\text { Preterm and } \\
\text { full-term infants }\end{array}$ & & Influenza & $\begin{array}{l}\text { to estimate the } \\
\text { effectiveness of } \\
\text { seasonal influenza } \\
\text { vaccination in all } \\
\text { pre- and full-term } \\
\text { infants aged } 6-23 \\
\text { months examining } \\
\text { influenza-coded } \\
\text { ambulatory visits } \\
\text { (physician office and } \\
\text { ED visits) during } \\
\text { influenza season } \\
\text { periods. }\end{array}$ & $\begin{array}{l}\text {-Full vaccination was associated } \\
\text { with an overall } 19 \% \text { reduction in } \\
\text { ambulatory visits (HR }=0.81 \text {; } \\
95 \% \mathrm{CI}, 0.68-0.97) \\
\text {-Among preterm children, full } \\
\text { vaccination was associated with a } \\
\text { non-significant, } 28 \% \text { reduction } \\
(\mathrm{HR}=0.72 ; 95 \% \mathrm{CI}, 0.40-1.29) \text {. } \\
\text {-Partial vaccination appeared } \\
\text { ineffective in all groups. }\end{array}$ & \\
\hline $\begin{array}{l}\text { Rückinger } \\
\text { et al (2010) } \\
68\end{array}$ & $\begin{array}{l}\text { active } \\
\text { prospective } \\
\text { surveillance } \\
\text { trial }\end{array}$ & $\begin{array}{l}766,999 \text { in } 2000 \\
684,862 \text { in } 2007\end{array}$ & 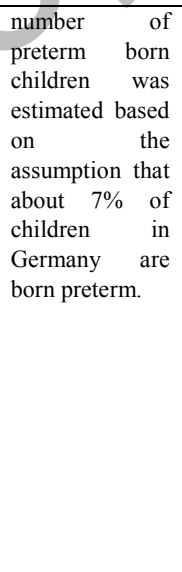 & Germany & PCV7 & $\begin{array}{l}\text { To evaluate the } \\
\text { impact of PCV7 on } \\
\text { IPD in preterm born } \\
\text { infants comparing } \\
\text { children born in } \\
2000 \text { (the only birth } \\
\text { cohort of } \\
\text { unvaccinated } \\
\text { children) with those } \\
\text { born in } 2007\end{array}$ & $\begin{array}{l}\text { - A reduction in notifications of } \\
\text { IPD per } 100,000 \text { from } 15.0 \text { to } 8.5 \\
(\mathrm{P}<0.001) \text { in } 2007 \text { was found. } \\
\text {-A reduction in notification rate } \\
\text { from } 26.1 \text { to } 16.7 \text { per } 100,000 \\
\text { comparing the } 2000 \text { with the } \\
2007 \text { was found also in preterm } \\
\text { birth cohort but it was not } \\
\text { significant }(\mathrm{P}=0.39) \\
\text { - No preterm infants with } \\
\text { reported IPD had received full } \\
\text { vaccination with booster dose } \\
\text { according to the recommended } \\
\text { scheme. In two cases a serotype } \\
\text { included in PCV7 was found. } \\
\text { These two cases had not received } \\
\text { pneumococcal vaccination prior } \\
\text { to disease onset, although they } \\
\text { were at an appropriate age. }\end{array}$ & $\begin{array}{l}\text { - exact number } \\
\text { of preterm born } \\
\text { infants in } \\
\text { Germany is } \\
\text { unknown }\end{array}$ \\
\hline
\end{tabular}




\begin{tabular}{|c|c|c|c|c|c|c|c|}
\hline $\begin{array}{l}\text { Hviid } \\
(2009) 71\end{array}$ & $\begin{array}{l}\text { Observational } \\
\text { retrospective } \\
\text { nationwide } \\
\text { cohort study }\end{array}$ & $\begin{array}{l}879,424 \\
\text {-preterm infants } \\
59,311 \\
\text {-full term infants } \\
820,113\end{array}$ & $\geq 20$ & Denmark & $\begin{array}{l}\mathrm{Pw} \text { and } \mathrm{Pa} \\
\text { vaccine }\end{array}$ & \begin{tabular}{lr}
\multicolumn{2}{l}{ Effectiveness of two } \\
pertussis vaccines in \\
preterm \\
children & Danish \\
evaluation & through \\
pertussis & \\
hospitalisation
\end{tabular} & $\begin{array}{l}\text {-For whole-cell vaccinated } \\
\text { children, the difference in } \\
\text { effectiveness estimated between } \\
\text { preterm and full-term children } \\
\text { was statistically significant ( } \mathrm{p}= \\
0.0134) \text {. } \\
\text {-We found that preterm children } \\
\text { were at } 91 \% \text { increased risk ( } 95 \% \\
\text { CI, } 21-200 \% \text { ) compared to full- } \\
\text { term children after one dose of } \\
\text { whole-cell vaccine. }\end{array}$ \\
\hline
\end{tabular}

Table 5 Studies regarding vaccine effectiveness in preterm infants. [Notes: $\mathrm{DTaP}=\mathrm{diphtheria,}$ tetanus, acellular pertussis vaccine; IPV= inactivated polio vaccine; OPV=oral polio vaccine; $\mathrm{HBV}=$ hepatitis B vaccine; PCV7 heptavalent antipneumococcal vaccine; PCV13= tridecavalent antipneumococcal vaccine; $\mathrm{Hib}=$ type $\mathrm{B}$ Haemophilus influenzae vaccine; Hib-MenC-TT= Haemophilus influenza type $B-N e i s s e r i a$ meningitidis serogroup $C$ vaccine; $B C G \Leftrightarrow B$ acille Calmette-Guérin vaccine; PHID-CV =PCV10-non typeable H. influenzae protein D conjugate vaccine; SNAP-II: Score for Neonatal Acute Physiology II (SNAP-II), MMR=measles, mumps, and rubella vaccine; $\mathrm{GMCs}=$ geometric mean concentrations; $\mathrm{PRP}=$ anti-polyribosylribitolphosphate; IPD= invasive pneumococcal disease; LMIT=leukocyte migration inhibition test, IC=interval confidence; $\mathrm{ED}=$ emergency department; $\mathrm{HR}=$ Adjusted hazard ratios; $\mathrm{Pw}=$ pertussis whole vaccine; $\mathrm{Pa}=$ pertussis acellular vaccine]. 


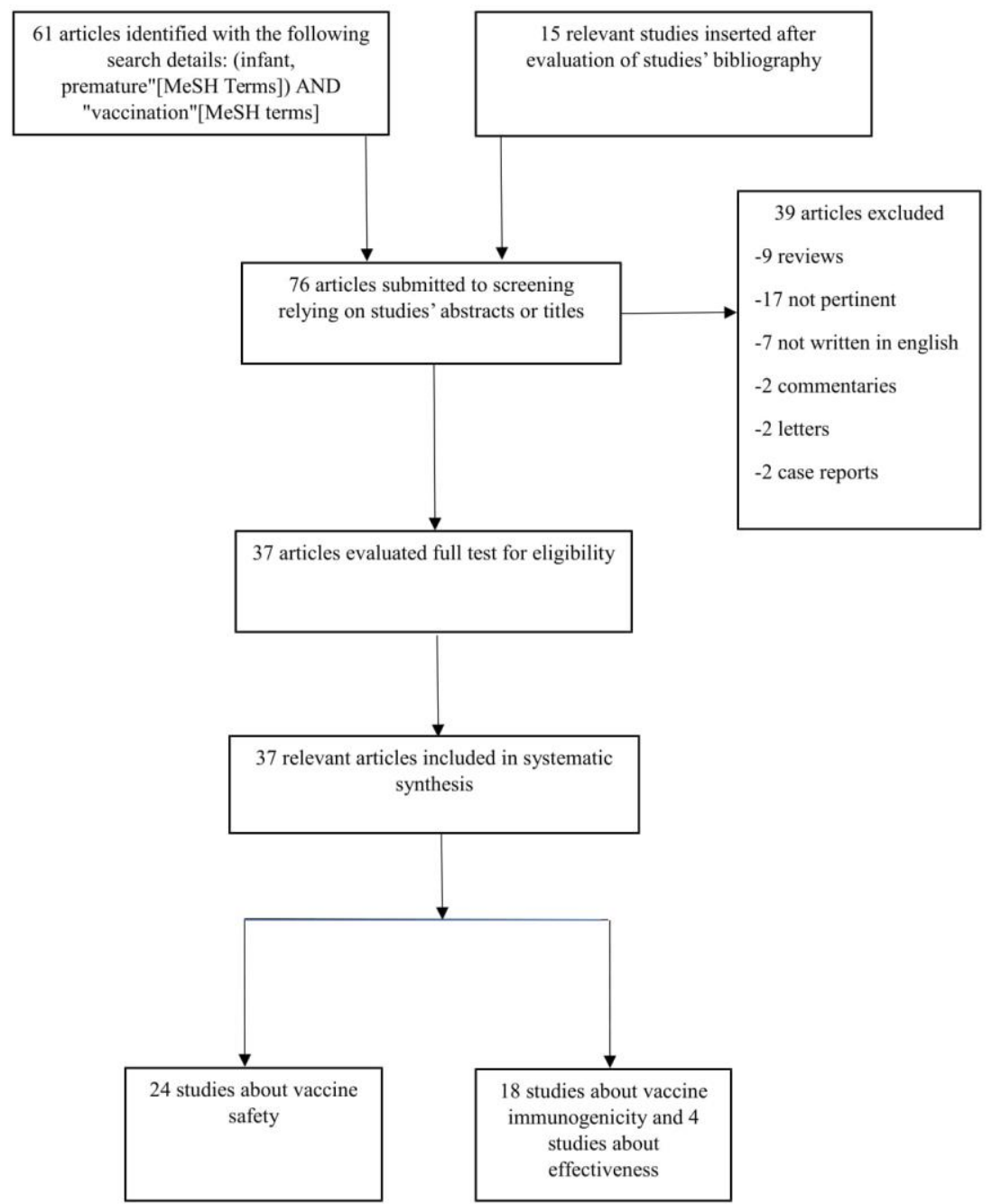

Figure 1: Four-phase flow diagram of the systematic review in accordance with PRISMA guidelines[40].

\section{Figure 1}

Four-phase flow diagram of the systematic review in accordance with PRISMA guidelines[40]. 